\title{
Demokratyczna transformacja w Polsce i na Ukrainie w świetle współczesnej tranzytologii: analiza porównawcza
}

\author{
Democratic transformation in Poland \\ and Ukraine in the light of modern transitology: \\ a comparative analysis
}

\author{
Natalia Rudakiewicz*
}

\begin{abstract}
Abstrakt
Polska i Ukraina stanowią dwa odmienne przykłady państw postkomunistycznych, w których procesy demokratyzacji wykazują różne tempo, determinanty oraz rezultaty. Celem postawionym w artykule jest próba określenia teoretycznych podstaw procesu demokratycznej transformacji w Polsce i na Ukrainie. Dokonano analizy porównawczej przemian systemowych w dwóch sąsiadujących państwach, ze szczególnym uwzględnieniem uwarunkowań determinujących te procesy. Artykuł powstał $\mathrm{z}$ potrzeby udzielenia odpowiedzi na pytanie: Jakie znaczenie mają doświadczenia polskiej i ukraińskiej transformacji systemowej dla współczesnej tranzytologii.
\end{abstract}

\begin{abstract}
Poland and Ukraine are two different examples of post-communist countries in which democratization processes exhibit different pace, determinants and results. The main aim of this article is to define the theoretical basis of the democratic transformation processes in Poland and Ukraine. A comparative analysis of systemic changes in two neighboring countries has been made, regarding specific determinants influencing these processes. Article arose from the need to answer the question: What is the significance of the experience of Polish and Ukrainian systemic transformation for modern transitology.
\end{abstract}

* doktorantka (n.rudakiewicz@gmail.com); iD https://orcid.org/0000-0001-5671-0915. 
Słowa kluczowe: transformacja, demokratyzacja, konsolidacja, determinanty, społeczeństwo obywatelskie, elity polityczne, kultura polityczna
Keywords: transformation, democratization, consolidation, determinants, civil society, political elites, political culture.

Po upadku reżimów komunistycznych w Europie Środkowej i Wschodniej państwa tego regionu podjęły wielki wysiłek na rzecz budowania skonsolidowanej demokracji. Spowodowało to nową falę badań w zakresie tranzytologii subdyscypliny politologii, zajmującej się wyjaśnieniem transformacji systemowej. Po dwudziestu pięciu latach tego procesu demokracje postkomunistyczne napotykają coraz większe wyzwania, co aktywizuje dyskusje wśród badaczy, a także powoduje, iż problematyka demokratycznej transformacji jest obecnie aktualna jak nigdy dotąd.

By zrozumieć istotę demokratycznej transformacji, należy zwrócić szczególną uwagę na znaczenie takich terminów, jak „transformacja systemowa”, „tranzycja” oraz „demokratyzacja”. Polski badacz Zbigniew Blok definiuje transformację systemową jako „wielki, globalny proces społeczny, który sięga głęboko we wszystkie podsystemy systemu społecznego"l. Autor dalej zaznacza, iż w procesie tym szczególna rola przypada systemowi polityczne$\mathrm{mu}$, ale o jego powodzeniu zadecydują jakościowe zmiany w systemie ekonomicznym. Równolegle z tymi zmianami, w kluczowych dla procesu transformacji systemach, zachodzą zmiany w strukturze społecznej. Ostatecznie proces ten zostanie zakończony dopiero wtedy, kiedy zostanie odwzorowany w świadomości społecznej i kiedy wartości, wyrosłe na bazie nowej jakości systemu społecznego, zostaną zinterioryzowane przez znaczące grupy i warstwy społeczne. Witold Morawski zmianę systemową definiuje jako „proces tworzenia się i krystalizowania nowych reguł w trzech sferach: polityce, gospodarce i społeczeństwie" ${ }^{2}$. Warto podkreślić, że termin "demokratyzacja” jest bardziej precyzyjny, ponieważ zawiera kierunek zmian systemowych, a mianowicie budowanie demokracji, dlatego należy utożsamiać demokratyzację z demokratyczną transformacją systemową. Następną kluczową kategorią dla tranzytologii jest termin „tranzycja” (ang.: transition, transit; ukr: nepexid; pol. przejście). Marzena Cichosz stosuje ten termin na określenie jednej z pierwszych, stosunkowo krótkotrwałych, faz zmian systemowych, obejmujących podejmowanie decyzji o zmianie systemu i tworzenie ogólnych ram funkcjonowania nowego systemu33. Ukraińska badaczka Anto-

1 Z. BLoK: Transformacja jako konwersja funkcji. Poznań 2006, s. 108.

2 W. Morawski: Zmiana instytucjonalna. Warszawa 1998, s. 12.

3 M. Cichosz: Transformacja demokratyczna - przyczyny, przebieg i efekty procesu. W: Systemy polityczne Europy Środkowej $i$ Wschodniej. Perspektywa porównawcza. Red. A. Antoszewski. Wrocław 2006, s. 35. 
nina Kolodii twierdzi, że „pojęcie przejścia [tranzycji — N.R.] odzwierciedla osobliwości takich społecznych transformacji, które znajdują się na krawędzi pomiędzy rewolucją a radykalnymi reformami. Przejście zmienia w sposób kardynalny podstawowe instytucje społeczne i w tym aspekcie jest rewolucyjne. Jednocześnie inicjatorzy i zwolennicy reform nie rezygnują z ram prawnych poprzedniego reżimu, transformując je stopniowo, dlatego w tym kontekście przejście jest podobne do ewolucyjnych procesów". Innymi słowy, przejście łączy w sobie rewolucyjne zadania (zamiana jednego politycznego czy społecznego ładu na inny) z ewolucyjnymi metodami ich realizacji. Natomiast transformację autorka rozumie jako proces głębokich zmian w społeczeństwie, które w pierwszej kolejności poruszają instytucjonalne podstawy obecnego porządkus.

Za jedną $\mathrm{z}$ najbardziej gruntownych prób stworzenia teorii przemian demokratycznych uważa się model z 1970 roku, zaproponowany przez Dunkwarta Rustowa. Jest to próba udoskonalenia teorii politycznej modernizacji, uzupełnienia oraz eliminowania jej wad. Ważnym wkładem w opracowanie teoretyczno-metodologicznych podstaw badań nad transformacją systemową było oddzielenie podejścia genetycznego od funkcjonalnego i zwrócenie uwagi na rolę istniejących oraz nowo powstających czynników proceduralnych. Rustow odrzucił stwierdzenie, iż przejście różnych państw do demokracji w różnych okresach historycznych jest uwarunkowane wpływem tych samych czynników. Autor stwierdził, że determinanty zabezpieczające stabilność demokracji nie są takie same jak te, które miały miejsce w początkowym etapie tranzycji ${ }^{6}$. Rustow sformułował dynamiczny model przejścia do demokracji składający się z trzech etapów: 1) fazy preparacyjnej - polegającej na wyłonieniu konfliktów w społeczeństwie; 2) fazy podejmowania decyzji - w trakcie której konflikty rozwiązywane są w sposób pokojowy lub rewolucyjny (próbuje się osiągnąć „wielki kompromis" pomiędzy aktorami politycznymi oraz wprowadzić polityczne reguły demokratycznej gry); 3) fazy przyzwyczajenia demokratycznego - objawiającej się zakorzenieniem norm demokratycznych w zachowaniu polityków i społeczeństwa. Taki trójetapowy proces demokratyzacji stał się modelem dla następnych badań w dziedzinie tranzytologii, na których podstawie wypracowano wiele koncepcji, dzielących proces demokratyzacji na poszczególne etapy.

${ }^{4}$ A. Kolodis: Politiczna transformacija w Ukraini: institucyi ta ludy. „Efektywnist' derżawnogo uprawlinnia" 2007, wyp. 12. Lwiw, s. 205.

5 A. KoloDiI: Trajektoria demokratycznego przejścia na Ukrainie. W: Transformacja $w$ Polsce i na Ukrainie. Wybrane aspekty. Red. A. Antoszewski, A. Kolodi, K. KowalCZYK. Wrocław 2010, s. 23.

${ }^{6}$ D. Rostou: Perechody $w$ demokratii: popytka dinamiczeskoj modeli. „Polis” 1996, № 5 , s. 5-15. 
Należy również zaznaczyć, iż Rustow za podstawowy warunek udanej demokratyzacji uważał jedność narodową, tak jak jej brak może spowodować poważne problemy w tym procesie.

Kolejną przełomową pracą w dziedzinie tranzytologii stała się Trzecia fala demokratyzacji Samuela Huntingtona. Praca ta stanowi próbę wyjaśnienia zbiorowych przypływów i odpływów demokracji, a zwłaszcza procesów rozpoczętych w połowie lat siedemdziesiątych XX wieku, które autor określił mianem „trzeciej fali”. Ważnym wkładem dla tranzytologii są założenia Huntingtona, które stały się podstawą „klasycznego paradygmatu tranzycji”. Po pierwsze, wyróżnił on trzy rodzaje przejść (przemieszczenie, transformacja lub zastąpienie), które opierają się na kryterium zaangażowania grup aktorów politycznych, w tym głównie elit władzy i opozycji. Po drugie, autor stwierdzil, iż proces demokratycznego przejścia ma charakter diachroniczny i składa się z trzech faz: upadek reżimu niedemokratycznego, ustanowienie demokratycznego reżimu i konsolidacja demokratycznego reżimu. Po trzecie, Huntington wysnuł wiele ważnych wniosków dotyczących roli determinant w przemianach demokratycznych?

Po rozpadzie Związku Radzieckiego większość państw postkomunistycznych wybrała demokrację liberalną jako kierunek transformacji systemowej, o czym świadczą uchwalone w tych krajach ustawy zasadnicze. Szczególnie aktywną debatę w kołach naukowych spowodowała demokratyzacja w państwach powstałych na gruzach ZSRR. Doświadczenie pierwszych lat zmian systemowych w państwach tych zademonstrowało, iż liniowe przejście od totalitarnego reżimu do demokracji jest kwestią wątpliwą. Bardzo szybko optymizm badaczy (dotyczący perspektyw demokratyzacji w tym regionie) zmienił się w sceptycyzm. Zaistniała potrzeba przemyślenia klasycznego paradygmatu tranzytologicznego.

Tranzytolodzy zauważyli, iż okoliczności, w których odbywa się przejście od komunizmu do postkomunistycznej demokracji, różnią się od tych, które dokonały się wcześniej w innych regionach świata. Na przykład Juan J. Linz i Alfred Stepan wyróżniają dodatkowe przeszkody na drodze demokratyzacji w Europie postkomunistycznej, które nie występowały w Ameryce Łacińskiej ani w Europie Południowej: ograniczona suwerenność (narzucona z zewnątrz władza hegemoniczna przeszkodziła tym państwom w budowaniu demokracji); jednoczesność transformacji politycznej i gospodarczej; dziedzictwo totalitaryzmu (Linz i Stepan twierdzą, iż tylko Polsce udało się uniknąć totalitaryzmu); słabość społeczeństwa obywatelskiego; prawosławie nie stało się siłą napędową dla opozycji, ponieważ historycznie było zależne od państwa (w przeciwieństwie do katolicyzmu i protestantyzmu); negatywne postrzeganie partii

${ }^{7}$ S.P. Huntington: Trzecia fala demokratyzacji. Przeł. A. Dziurdzik. Warszawa 1995, s. 121 . 
politycznych w społeczeństwie; brak tradycji rządów prawa i kultury konstytucjonalizmu; dziedzictwo byłego reżimu imperialno-totalitarnego objawiające się w braku zaufania społecznego ${ }^{8}$.

Analizując uwarunkowania, w których odbywa się przejście od komunizmu do postkomunistycznej demokracji, badacze zaczęli mówić o modelu potrójnej (triple) tranzycji w państwach postkomunistycznych, który polega na transformacji politycznej, gospodarczej oraz procesie państwotwórczym (state-building) ${ }^{9}$. Polska odegrała szczególną rolę w przemianach demokratycznych Europy Środkowej i Wschodniej, ponieważ zmiany polityczne w tym państwie zainicjowały efekt domina $\mathrm{w}$ całym regionie ${ }^{10}$. Proces modernizacji w Polsce nabrał niespotykanego wcześniej tempa, co uczyniło to państwo regionalnym liderem na tle innych państw pokomunistycznych. Polska po roku 1989 konsekwentnie podążała w kierunku skonsolidowanej demokracji - udało się zrealizować model transformacji, polegający na szybkich, zdecydowanych reformach w sferze politycznej i gospodarczej. We wdrażaniu tego rodzaju transformacji w regionie Europy Środkowej i Wschodniej, Polska i Estonia są bezwzględnymi liderami. Polsce przede wszystkim udało się ukształtować pluralistyczny system partyjny, zagwarantować szeroki katalog wolności i praw obywatelskich, a także ukształtować instytucje chroniące demokrację. Natomiast w sferze gospodarki udało się wprowadzić wolnorynkowe zasady w system gospodarczy ${ }^{11}$.

Transformacja systemowa w Polsce dokonywała się w odmienny sposób niż transformacja systemowa na Ukrainie. O ile w Polsce rezultatem wdrażanych reform stało się wejście od 1997 roku do trzeciego etapu demokratycznej transformacji - konsolidowania się demokracji, o tyle na Ukrainie system balansował między demokracją elektoralną a autorytaryzmem. Międzynarodowa organizacja pozarządowa Freedom House monitorująca przypadki naruszenia wolności wypowiedzi na całym świecie i prowadzącą kampanie na rzecz dziennikarzy, pisarzy i obrońców praw człowieka, zalicza Polskę do demokracji skonsolidowanych, natomiast Ukraina w ocenie Freedom House pozostaje reżimem hybrydowym (por. tab. 1):

8 J.J. Linz, A. Stepan: Problems of Democratic Transition and Consolidation. Southern Europe. Baltimore 1996, s. 250.

9 T. Kuzio: Transition in Post-Communist States. Triple or Quadruple? „Politics” 2001, Vol. 21(3), s. 168.

${ }^{10}$ B. Dobek-Ostrowska: Proces demokratyzacji Europy Środkowo-Wschodniej - przestanki i przebieg. W: Demokracje Europy Środkowo-Wschodniej w perspektywie porównawczej. Red. A. Antoszewski, R. Herbut. Wrocław 1998, s. 12.

${ }^{11}$ L. BALCEROWICZ: Socjalizm, kapitalizm, transformacja. Szkice z przełomu epok. Warszawa 1997, s. 196. 
Tabela 1

Dynamika rozwoju demokracji w Polsce i na Ukrainie według wyliczeń Freedom House ${ }^{12}$

\begin{tabular}{|l|c|c||c|c|c|}
\hline \multirow{2}{*}{ Lata } & \multicolumn{2}{|c||}{ Kraj } & \multirow{2}{*}{ Lata } & \multicolumn{2}{c|}{ Kraj } \\
\cline { 2 - 3 } & Polska & Ukraina & & Polska & Ukraina \\
\hline $1999-2000$ & 1.58 & 4.63 & 2010 & 2.32 & 4.39 \\
\hline 2001 & 1.58 & 4.71 & 2011 & 2.21 & 4.61 \\
\hline 2002 & 1.63 & 4.92 & 2012 & 2.14 & 4.82 \\
\hline 2003 & 1.75 & 4.71 & 2013 & 2.18 & 4.86 \\
\hline 2004 & 1.75 & 4.88 & 2014 & 2.18 & 4.93 \\
\hline 2005 & 2.00 & 4.50 & 2015 & 2.21 & 4.75 \\
\hline 2006 & 2.14 & 4.21 & 2016 & 2.32 & 4.68 \\
\hline 2007 & 2.36 & 4.25 & 2017 & 2.57 & 4.61 \\
\hline 2008 & 2.39 & 4.25 & 2018 & 2.89 & 4.64 \\
\hline 2009 & 2.25 & 4.39 & & & \\
\hline
\end{tabular}

Źródło: https://freedomhouse.org/report/nations-transit/2018/poland (dostęp: 22.10.2018)

Ukraińscy naukowcy w różny sposób charakteryzują postkomunistyczną transformację na Ukrainie, ale wszyscy podkreślają jej niekonsekwentny charakter. Aleksander Motyl zaznacza, iż przemiany demokratyczne na Ukrainie przypominają „błądzenie” (muddling on) ${ }^{13}$. Określenie to szybko się rozpowszechniło w ukraińskiej literaturze tranzytologicznej — zaczęli go używać w różnych interpretacjach tacy badacze, jak Dominique Arel ${ }^{14}$ i Katarzyna Wolczuk $(2002)^{15}$.

Tranzytolog Antonina Kolodii w swoich badaniach zaznacza, iż trajektorię demokratycznej transformacji na Ukrainie można porównać do „zygzaka”, ponieważ ma charakter nieliniowy (niepłynny) oraz zmierza wolnymi krokami to $\mathrm{w}$ stronę liberalnej demokracji, to $\mathrm{w}$ stronę autorytaryzmu ${ }^{16}$. W swoim artykule

12 Według zastosowanej metodologii monitoringu, reżim polityczny, którego skala demokratyzacji jest na poziomie $1-2,99$, określano jako demokrację skonsolidowaną (consolidated democracy); reżim demokratyczny, którego skala demokratyzacji lokuje się na poziomie 3-3,99, określano „demokracją połowicznie skonsolidowaną” (semiconcolidated demokracy); na poziomie 4-4,99 znajduje się „reżim hybrydowy” (hybrid regime); 5-5,99 — „połowicznie skonsolidowany reżim autorytarny” (semiconsolidated autoritarian regime); na poziomie 6-7 - „skonsolidowany reżim autorytarny” (consolidated autoritarian regime). Poziom demokracji Freedom House wylicza na podstawie wyników indeksów poziomu demokratyzacji i poziomu rozwoju państwa prawa.

${ }^{13}$ O. Motyl: Jak zrozumity Ukrainu? „Kritika” 1998, № 1(3).

${ }^{14}$ D. Arel: Ukraine: The Muddle Way. "Current History" 1998, No 8, s. 342-346.

${ }^{15}$ K. Wolczuk: The Moulding of Ukraine. The Constitutional Politics of State Formation. Budapest 2002, s. 315.

${ }^{16}$ A. Kolodis: Zagalmowana transformacija i majbutne ukrains'koj mrii pro demokratycznu prawowu derżawu — http://political-studies.com/?p=901 (dostęp: 20.10.2018). 
autorka wyodrębnia następujące etapy przemian systemowych na Ukrainie: lata 1987-1990 - liberalizacja; 1990 - 1994 — demokratyzacja; 1992-1999 uchwalenie decyzji odnośnie do zmiany instytucji w sferach gospodarczej i politycznej. Dalej autorka pisze, że od roku 1997 mogła się zacząć faza konsolidowania się demokracji. Jednak etap ten nie nastąpił, ponieważ w latach 1997-2000 zaczął się oligarchiczny etap rozwoju państwa. W latach 20002004 - biurokratyczno-oligarchiczny autorytaryzm był w połowie zinstytucjonalizowany. Po pomarańczowej rewolucji w latach 2004-2009 odbywało się wznowienie demokratycznego przejścia oraz elektoralnej demokracji. Z kolei od 2010 roku instytucjonalizuje się oligarchiczny autorytaryzm. Kontynuując rozważania Kolodii, możemy określić lata 2014-2018 jako wznowienie demokratycznej transformacji i ustanowienie ponownie demokracji elektoralnej. Analiza trajektorii zmian systemowych na Ukrainie demonstruje częste zwalnianie tempa reform oraz potrzebę nadrabiania szkód wyrządzonych w poprzednich etapach rozwoju państwa. Sprawia to, iż perspektywa wejścia w trzecią fazę konsolidowania demokracji jest daleka, ponieważ sama trajektoria przemian ma charakter niekonsekwentny i nieprzewidywalny.

Badacze wnioskują, iż model szybkiej transformacji systemowej zrealizowany w Polsce nie może być efektywnie zrealizowany na Ukrainie ${ }^{17}$. By wyjaśnić taki wniosek, należy uważnie przyjrzeć się specyficznym determinantom, które sprawiły, iż trajektorie demokratyzacji w porównywanych państwach wyglądają całkowicie odmiennie.

Wśród kluczowych czynników, które wywarły decydujący wpływ na charakter i tempo demokratyzacji w Polsce i na Ukrainie, należy wyróżnić następujące:

— doświadczenie przeszłości;

- aktywność społeczeństwa obywatelskiego (zwłaszcza w pierwszej fazie przemian ustrojowych);

— polityka elit rządzących;

— wpływ otoczenia międzynarodowego (szczególnie Rosji).

\section{Doświadczenia z przeszłości}

Dziedzictwo historyczne stanowi decydujący czynnik wpływający na proces demokratyzacji na wszystkich jego etapach. Jest to jedna $\mathrm{z}$ kluczowych deter-

17 Zob.: K. Falkowski: Testing the CEE's Model of Transformation in the ENP Framework. Challenges and Opportunities. The Eastern Dimension. "Yearbook of the Institute of East-Central Europe" 2016, Vol. 14, No 6, s. 9-25. 
minant procesu demokratyzacji w państwach postkomunistycznych, która wyznacza tempo i zaawansowanie przemian demokratycznych. W literaturze politologicznej wielokrotnie zaznaczano, iż państwa postkomunistyczne odnoszące sukcesy w procesie demokratyzacji miały w przeszłości jakieś doświadczenia rządów demokratycznych. Wpływ tradycji na budowanie demokracji w państwie polega przede wszystkim na odwołaniu się do zasad, wartości i reguł zachowań, które są sprawdzone i nadal postrzegane w społeczeństwie jako dobre. Społeczeństwa, które doświadczyły demokracji w przeszłości, odznaczają się wyższym poziomem akceptacji demokratycznego stylu życia niż te, które nie miały możliwości doświadczyć demokracji w swojej historii. Odmienne typy dziedzictwa historycznego Polski i Ukrainy wywarły istotny wpływ na początkowy etap demokratycznej transformacji oraz wyznaczyły dalszy charakter procesu przemian.

Polska ma doświadczenia demokratyczne z okresu międzywojennego - lata od 1918 do 1926. W marcu 1921 roku została uchwalona Konstytucja Rzeczypospolitej Polskiej, która uczyniła zasadę podziału władzy fundamentem wzajemnych relacji pomiędzy organami państwowymi. Konstytucja wprowadzała system parlamentarno-gabinetowy jako model relacji między naczelnymi organami państwowymi. Wprowadzono system dwuizbowy ciała ustawodawczego, w którym prymat należał do Sejmu (art. 2). Na czele władzy wykonawczej stał prezydent Rzeczypospolitej, a władza sądownicza została powierzona niezawisłym sądom (art. 2). W zaproponowanym reżimie politycznym rola parlamentu była znacząca, natomiast egzekutywa nie posiadała szerokich uprawnień. Należy zaznaczyć, iż w okresie międzywojennym funkcjonowała instytucja Trybunału Stanu ${ }^{18}$.

Po II wojnie światowej wszystkie państwa Europy Środkowej i Wschodniej dostały się pod wpływ Związku Radzieckiego oraz były poddane sowietyzacji. W Polsce system represji wobec opozycji uchodził za najbardziej łagodny w tym regionie, a reżim totalitarny nigdy nie został w pełni zainstalowany. W okresie PRL-u nie zniknęły określone formy pluralizmu społecznego, jak to było na przykład w USRR, gdzie liberalizacja życia społecznego rozpoczęła się dopiero w 1987 roku.

W Polsce przed 1947 rokiem, gdy proces sowietyzacji dopiero się zaczynał, oświata i kultura rozwijały się w warunkach znacznej swobody i nie były poddawane ideologicznej kontroli ${ }^{19}$. Mimo że w tym okresie stosowano represje wobec opozycji, jednak nie był to terror totalitarny. W latach 1947-1956 władze próbowały narzucić społeczeństwu totalitaryzm - stosowano represje policyjne wobec niewinnych ludzi, próbowano podporządkować sobie Kościół Katolicki, któremu jednak udało się zachować samodzielność wobec państwa.

18 W. Komarnicki: Polskie prawo polityczne (geneza i system). Warszawa 1922, s. 478.

19 J. Wiatr: Polska droga do demokracji ..., s. 32. 
W tym okresie doktryna marksizmu-leninizmu stała się oficjalnie podstawą w naukach społecznych i kulturze. Zlikwidowano dotychczas istniejące formy pluralizmu społecznego i politycznego. Utworzono Polską Zjednoczoną Partie Robotniczą, która oficjalnie odwoływała się do komunistycznej ideologii. W celu budowania kontrolowanej przez państwo gospodarki, prowadzono politykę kolektywizacji w rolnictwie oraz niszczono sektor prywatny. W latach 1956 - 1980 poziom represyjności znacząco się obniżył, co objawiało się w zaprzestaniu ingerencji partii w sprawy kultury i nauki. W okresie tym dokonywało się odejście od totalitaryzmu, liberalizacja dotyczyła różnych aspektów życia. Polska Zjednoczona Partia Robotnicza nadal odgrywała dominującą rolę w państwie, natomiast jej stosunki ze Zjednoczonym Stronnictwem Ludowym i Stronnictwem Demokratycznym stawały się bardziej partnerskie. Po 1956 roku polscy przywódcy uwolnili się spod presji sowietyzacyjnej, z jednej strony podejmowali decyzje zgodnie z racją stanu, a drugiej strony zachowywali samodzielność w sprawach wewnętrznych. Wyraźnie poprawiły się stosunki władz państwowych z Kościołem Katolickim, zaprzestano sięgania do środków przymusu wobec tej instytucji. Nastąpiła odwilż w polityce gospodarczej, co skutkowało rozwojem sektora prywatnego w gospodarce. Zachodziły zmiany w ideologii partii rządzącej, zaczęto propagować konieczność zaspokojenia potrzeb ludności. W latach siedemdziesiątych i osiemdziesiątych XX wieku polski ruch demokratyczny uzyskał charakter masowy. Powstanie Niezależnego Samorządnego Związku Zawodowego „Solidarność” świadczyło o istnieniu potężnej siły opozycyjnej, co podważało podstawy systemu autorytarnego. Powołany w 1980 roku związek zawodowy „Solidarność” w okresie swojej największej popularności liczył $10 \mathrm{mln}$ członków — z $12 \mathrm{mln}$ pracowników przemysłowego sektora gospodarki ${ }^{20}$.

Po wprowadzeniu stanu wojennego w 1981 roku aresztowano dziesiątki tysięcy uczestników antykomunistycznej opozycji. Jednak należy zauważyć, iż na tle innych państw regionu autorytarny system wojskowy w Polsce stał się jedynym z bloku państw komunistycznych, w którego ramach jawnie działały opozycyjne struktury cieszące się masowym poparciem społecznym (Krajowa Komisja Wykonawcza NSZZ „Solidarność” ${ }^{21}$. W tym okresie władze przeprowadzały reformy w sferze ekonomicznej i politycznej) ${ }^{22}$. Należy także zaznaczyć, iż polityka Michaiła Gorbaczowa od 1985 roku pozwoliła na większą libe-

${ }^{20}$ E. Bronislawskiu, G. Wacznadze: Polskij dialog. Sobytija w Polsze glazami polskich, sowetskich, amerikanskich, zapadnogermanskich i francuskich żurnalistow. Tbilisi 1990, s. 13.

21 A. Piasecki, R. Michalak: Polska 1945-2015. Historia polityczna. Warszawa 2016, s. 173.

${ }^{22}$ M. KowalsKa: Ombudsman $w$ procesie transformacji ustrojowej $w$ Polsce $i$ innych krajach europejskich. W: Modernizacja polityczna $w$ teorii i praktyce. Doświadczenia państw postsocjalistycznych i Trzeciego Świata. Red. M. BARAŃSKI. Katowice 2009, s. 80. 
ralizację wewnętrznej polityki oraz otworzyła drogę do dalszej demokratyzacji państwa.

W XX wieku Ukraina zdobyła bardzo krótkotrwałe doświadczenie swojej państwowości, przez cały wiek będąc pod okupacją innych państw. W dniu 9 stycznia 1918 roku została ogłoszona niezależność Ukraińskiej Republiki Ludowej (URL) od Rosji na mocy IV Uniwersalu uchwalonego przez Centralną Radę. Za sukces URL można uznać podpisanie 27 stycznia 1918 roku traktatu brzeskiego, zgodnie z którym zobowiązywała się zaprzestać walki w I wojnie światowej, sama URL natomiast została uznana przez państwa takie, jak: Niemcy, Austro-Węgry, Bułgaria i Turcja. W pierwszym etapie istnienia niepodległego państwa Centralna Rada prowadziła aktywną działalność ustawodawczą. Dnia 29 kwietnia 1918 roku Centralna Rada uchwaliła Konstytucję URL oraz wybrała prezydenta - Mychajłę Hruszewskiego ${ }^{23}$.

Uchwalenie Konstytucji stało się swoistym podsumowaniem procesu politycznego toczącego się od marca 1917 roku. Wydarzenie to stworzyło konstytucyjne podstawy państwa ukraińskiego oraz stało się czynnikiem sprzyjającym konsolidacji społeczeństwa. Najwyższa władza w państwie została powierzona Zgromadzeniu Ogólnonarodowemu, którego kompetencje polegały na wykonywaniu zadań władzy ustawodawczej oraz tworzeniu organów władzy wykonawczej i sądowniczej (art. 23), jakimi były: Rada Ministrów i Sąd Generalny URL (art. 24 i 25). Parlamentarzyści Zgromadzenia Ogólnonarodowego wybierali jednego przedstawiciela na urząd przewodniczącego Zgromadzenia, który zgodnie $\mathrm{z}$ art. 35 konstytucji UNR miał sprawować swe czynności w imieniu Republiki. Na mocy konstytucji, przewodniczący i jeden z sekretarzy Zgromadzenia zobowiązywali się podpisywać pod aktami parlamentu. W taki sposób przyznano Mychajle Hruszewskiemu prawo kontroli ustaw i postanowień wydawanych przez Zgromadzenie Ogólnonarodowe (art. 43). Do kompetencji Przewodniczącego Zgromadzenia należało także powoływanie członków rządu (art. 52). Rada Ministrów była odpowiedzialna przed Zgromadzeniem Ogólnonarodowym, które mogło uchwalić wotum nieufności stosunkiem głosów 2/3 deputowanych ${ }^{24}$.

Wybory do organu przedstawicielskiego URL (ukr: Українські Установчі Збори) były zaplanowane na 12 maja 1918 roku. Jednak w nocy z 29 na 30 kwietnia dokonał się przewrót, wskutek którego władzę przejął Pawło Skoropadski, który ogłosił się hetmanem. Jak zaznaczają ukraińscy badacze, pragnął on zjednoczyć wszystkie ukraińskie terytoria etniczne. Pod jego rządami nastąpiło narodowo-kulturalne odrodzenie - utworzono ukraińskie gimnazja, uniwersytety, Bibliotekę Narodową, Ukraińską Akademię Nauk itp. Jednak hetman

${ }^{23}$ Atlas istorii ukrains'koj derżawnosti. Ukrains'ki zemli wid najdawniszych czasiw do s'ogodennia. Red. O. Kupczyns'KiJ, J. Loza, O. Szablij. Lwiw 2013, s. 109.

${ }^{24}$ TrofanczuK G.: Istorija derżawy ta prawa Ukrainy. Nawczalnyj posibnyk. Kyiw 2017, s. 377. 
Skoropadski zrzekł się swojego urzędu, a władzę 14 grudnia 1918 roku przejął Dyrektoriat. W okresie tym w Galicji również próbowano stworzyć niezależne państwo - 19 października 1918 roku ogłoszono Zachodnioukraińską Republikę Ludową, która nie przetrwała roku. Państwowość ukraińska została na bardzo krótki czas przerwana, ponieważ 18 marca 1921 roku ZSRR i Polska podpisały traktat ryski, zgodnie z którym ówczesne tereny Zachodniej Ukrainy weszły w skład obszaru Polski, a reszta terytorium pozostała w granicach USRR ${ }^{25}$.

Wskutek represji stalinizmu zostało faktycznie wyniszczone całe pokolenie ukraińskiej inteligencji. Tylko w sprawie „Związek Wyzwolenia Ukrainy”26 represjonowano 45 wybitnych ukraińskich uczonych, pisarzy oraz innych przedstawicieli inteligencji (S. Jefremow, Wołodymyr Czechiwski, Andrij Nikowski, Mychajło Słabczenko, Wołodymyr Durdukiwśkyj). W latach trzydziestych XX wieku masowym represjom zostało poddane „rozstrzelane odrodzenie” — pokolenie ukraińskich artystów i naukowców działające w latach dwudziestych do początku lat trzydziestych XX wieku w USRR. Szczególnie tragiczna była jesień 1937 roku, kiedy w ciągu pięciu dni w uroczysku Sandarmoch w Karelii rozstrzelano 1111 więźniów obozu koncentracyjnego w Sołowkach. Ofiarami tej masowej egzekucji byli najbardziej jaskrawi ukraińscy twórcy i działacze społeczni: Mykoła Zerow, Łeś Kurbas, Mykoła Kulisz, Ołeksa Slisarenko, Mykoła Irczan, Wołodymyr Czerwiński, Pawło Fyłypowycz i inni. Ci, którym udało się przezyć, zostali skazani na podwójną twórczą działalność - balansowanie pomiędzy dysydenctwem a służeniem reżimowi.

W latach 1946-1947 władze radzieckie doprowadziły do trzeciej klęski głodu, wskutek czego zginęło $1 \mathrm{mln}$ mieszkańców wsi27. Powojenne represje stalinizmu dotknęły szczególnie zachodnią część Ukrainy. Dnia 8 marca 1946 roku zlikwidowano Ukraińską Grekokatolicką Cerkiew w Galicji, a w okresie stycznia i lutego 1949 roku — w Zakarpaciu. Dnia 11 kwietnia władze radzieckie przeprowadziły liczne aresztowania duchowieństwa, został aresztowany także biskup grekokatolicki Josyf Slipyj.

Po śmierci twórcy radzieckiego reżimu totalitarnego Józefa Stalina skala politycznych represji się zmniejszyła. Od 1956 roku rozpoczęła się stopniowa rehabilitacja więźniów z okresu masowego terroru, ale politycznych represji cał-

${ }^{25}$ GrYCAK J.: Narys istorii Ukrainy: formuwannia modernoj urkainsjkoj nacyi XIX $-X X$ stolittia. Kyiw 2000, s. 127-134.

${ }^{26}$ Związek Wyzwolenia Ukrainy był fikcyjną organizacją antyreżimową, powołaną przez władze radzieckie w celu dokonania identyfikacji oraz masowych aresztowań ukraińskiej inteligencji niekomunistycznej (tzw. starej inteligencji) w latach 1929-1930, procesu pokazowego w Charkowie na przełomie marca i kwietnia 1930 r. i kolejnych masowych represji wobec inteligencji naukowej i studentów po procesie.

${ }^{27}$ Pierwsza fala głodu w USRR miała miejsce w latach 1921-1923 wskutek niskiego zbioru plonów oraz dużego eksportu chleba za granicę, natomiast druga fala głodu była zorganizowana przez władze radzieckie w latach 1932-1933. W jej rezultacie zmarło $10 \mathrm{mln}$ osób (przeważnie Ukraińców). 
kowicie nie zaprzestano - nadal poszukiwano „wrogów władzy radzieckiej”. Tylko w latach 1954-1959 zlikwidowano 183 nacjonalistyczne i inne antyradzieckie organizacje i grupy, pociągnięto do odpowiedzialności karnej 1879 osób, których działalność uznano za niezgodną z linią polityki reżimu, użyto także środków profilaktycznych w stosunku do 1300 obywateli. Szczególnym osiągnięciem KGB było zidentyfikowanie 46 antyradzieckich grup, do których należały głównie inteligencja i młodzież ${ }^{28}$.

Po odsunięciu Nikity Chruszczowa od sprawowania władzy w ZSRR Leonid Breżniew objął urząd I sekretarza KC KPZR. Od 1956 roku zaczęła się nowa fala represji przeciwko ukraińskiej inteligencji. W aspekcie ekonomicznym rządy Breżniewa odznaczały się stagnacją w rozwoju przemysłu, dlatego często dochodziło do manipulacji w statystykach. Rozwijała się korupcja na szeroką skalę. Jako protest przeciwko polityce Breżniewa na Ukrainie oraz w innych republikach ZSRR powstał ruch dysydencki. Członkami ukraińskiego ruchu byli: Wiaczesław Czornowił, Łewko Łukjanenko, Iwan Dziuba, Jewhen Swerstiuk, Wasyl Stus. Dysydenci organizowali manifestacje, rozpowszechniali materiały informacyjne w społeczeństwie. Największe centra dysydenckie były ulokowane w zachodniej (miasta Łuck, Riwne, Tarnopol, Użhorod) oraz centralnej części Ukrainy (Kijów, Czerkasy, Żytomierz) ${ }^{29}$.

W latach 1966 i 1972 miały miejsce potężne fale aresztowań dysydentów. Oczywiście, represje te były nieporównywalne z tymi dokonanymi na milionach uwięzionych i deportowanych w latach 1930 - 1950. Jednak miały one wielkie znaczenie dla utrzymywania atmosfery strachu w społeczeństwie, ponieważ żywa była jeszcze pamięć o represjach stalinizmu, a wśród aresztowanych znajdowały się przede wszystkim znane postacie. Profilaktyczne represje w stosunku do niezgodnych z reżimem aktywistów trwały jednak dalej. Ostatni więźniowie ukraińscy opuścili więzienia dopiero w końcu 1988 roku.

Po dojściu do władzy w ZSRR Michaiła Gorbaczowa zaczął się okres ,,pieriestrojki”. W tym czasie zostały założone pierwsze legalne organizacje ukraińskie: Towarzystwo Języka Ojczystego im. Tarasa Szewczenki (reaktywowane 13 czerwca 1989 r. we Lwowie), Towarzystwo Języka Ukraińskiego (11-12 lutego 1989 r. w Kijowie), Stowarzyszenie „Memoriał” (4 marca 1989 r. w Kijowie), Ludowy Ruch Ukrainy (8—9 września 1989 r. w Kijowie) ${ }^{30}$.

Różne doświadczenia przeszłości Polski i Ukrainy przyczyniły się do tego, iż ruchy wyzwoleńcze $\mathrm{w}$ obu państwach na ostatnim etapie istnienia ZSRR istotnie się różniły. Trzeba zaznaczyć, iż polityczny ruch opozycyjny na Ukrainie składający się z wielu grup społecznych zyskał charakter masowy dosyć późno, w końcu lat osiemdziesiątych XX wieku. Wcześniej wszelkie przejawy

${ }^{28}$ Turczenko F., Panczenko P., Timczenko S.: Nowitnia istorija Ukrainy. Pidrucznik. Kyiw 2005, s. 53.

${ }^{29}$ Atlas istorii ukrains'koj derżawnosti..., s. 118.

${ }^{30}$ Ibidem, s. 119. 
ruchu narodowościowego na Ukrainie były eliminowane przez władze radzieckie. Ideowe oblicze ruchu opozycyjnego w końcu lat osiemdziesiątych XX wieku łączyło w sobie cechy narodowościowe i państwotwórcze, jednak nie poruszano kwestii ustroju politycznego, reform administracji, sfery socjalnej ani ekonomicznej. Wśród celów ruchu protestacyjnego na Ukrainie były nie tylko dążenia narodowościowe, lecz bardzo niesprecyzowane wymogi odnowienia sprawiedliwości społecznej oraz likwidacja przywilejów dla elit.

Kolejna różnica pomiędzy polskim a ukraińskim ruchem opozycyjnym polegała na tym, że w Polsce ruch na rzecz praw jednostki od połowy lat siedemdziesiatych połączył się z ruchem robotniczym, którego postulaty dotyczyły polepszenia warunków pracy oraz poziomu życia robotników. W 1976 roku ruchy dysydenckie i robotnicze się połączyły, kiedy to dysydenci - przedstawiciele inteligencji - stworzyli Komitet Obrony Robotników będący później podstawą robotniczej w znacznej mierze „Solidarności”. Polski ruch demokratyczny końca lat siedemdziesiątych miał charakter narodowo-patriotyczny i niepodległościowy. Wśród jego postulatów były hasła dotyczące demokratyzacji społeczeństwa, pluralizmu politycznego, a także obrony praw człowieka i obywatela. Należy zaznaczyć, iż głównym celem opozycyjnego ruchu masowego była obrona praw robotników. Wspólna ideowa platforma narodowościowo-demokratyczna połączyła w ramach „Solidarności” niezależne organizacje społeczne — od konserwatystów katolickich do ultralewicowych socjalistów. Tak szerokie podłoże ideologiczne oraz charakter masowy ruchu opozycyjnego przesądziły o pomyślności procesu demokratyzacji w tym państwie.

\section{Społeczeństwo obywatelskie}

Społeczeństwo obywatelskie stanowi kolejną ważną determinantę procesu demokratyzacji w Polsce i na Ukrainie. Odmienne doświadczenia w okresie przedtransformacyjnym sprawiły, iż aktywność społeczna w tych krajach w momencie przejścia od systemu niedemokratycznego do systemu demokratycznego była zasadniczo różna, co z kolei wpłynęło na to, jakie było późniejsze tempo reform demokratycznych. W Polsce pod wpływem protestów społecznych zdecydowano się na przeprowadzenie obrad Okrągłego Stołu, które stały się symbolem zmian w Polsce oraz w regionie Europy Środkowej i Wschodniej. W procesie decyzyjnym brały udział dotychczasowa opozycja antyreżimowa oraz stara elita, składająca się z obozu reformatorskiego i konserwatywnego. W wyniku porozumień osiągniętych w trakcie obrad Okrągłego Stołu zdecydowano się przeprowadzić wolne wybory do jednego z organów przedstawicielskich na poziomie ogólnokrajowym (senat) i częściowo wolne do kolejnego 
(sejm). Wypracowano układ instytucjonalny, który miał mieć charakter tymczasowy - obliczony na cztery lata. Jedną z najważniejszych decyzji było przywrócenie instytucji jednoosobowej głowy państwa do systemu naczelnych organów władzy państwowej.

W „otwierających” wyborach parlamentarnych w 1989 roku opozycyjny Komitet Obywatelski „Solidarność” niespodziewanie osiągnął zaskakująco duże poparcie. Społeczeństwo wykorzystało możliwość wypowiedzenia się przeciwko dotychczasowemu systemowi, która powstała dzięki obradom Okrągłego Stołu. Rezultat wyborów parlamentarnych z czerwca 1989 roku oznaczał faktyczne odwrócenie układu sił politycznych, który został ustalony w obradach okrągłostołowych. W wyniku tych wyborów koalicja, której przewodziła PZPR, zaczęła się rozpadać. PZPR przestała być monolitem, tracąc kontrolę nad własnym zapleczem parlamentarnym. W wyborach prezydenckich w 1989 roku wybrano Wojciecha Jaruzelskiego stosunkiem głosów 270 z 269 wymaganego minimum. W tym czasie dokonywały się zaawansowane procesy dezintegracji obozu władzy. Powołano rząd, na którego czele stanęła po raz pierwszy osoba spoza partii hegemonicznej - Tadeusz Mazowiecki, co oznaczało przejęcie władzy przez opozycję antyreżimową.

Należy nadmienić, iż w Polsce decydującą rolę po obradach Okrągłego Stołu odegrało aktywne społeczeństwo obywatelskie, które konsekwentnie dążyło do wymiany elit rządzących. Po uchwaleniu ustawy o wyborze prezydenta RP po raz pierwszy społeczeństwo miało możliwość wyboru prezydenta w powszechnych i bezpośrednich wyborach. Pierwsze takie wybory zakończyły się zwycięstwem w I turze lidera ruchu rewolucyjnego - Lecha Wałęsy. Prodemokratyczna kultura polityczna społeczeństwa i jego aktywny udział w życiu publicznym odegrały ważną rolę w początkowej fazie procesu demokratyzacji, w wyniku czego nastąpiła alternacja władzy, co oznaczało aktywny udział opozycji w procesie rządzenia państwem i przejęcie przez nią kierownictwa i odpowiedzialności za przebieg tego procesu.

Dla porównania, na Ukrainie w okresie przed rozpadem ZSRR nie doszło do zorganizowania masowego ruchu na rzecz reform, jak to było na przykład w Polsce czy państwach bałtyckich. Taką organizację stanowił Ludowy Ruch Ukrainy (LRU) założony w 1989 roku, będący koalicją składającą się z byłych dysydentów z Ukraińskiego Związku Helsińskiego oraz kijowskiej inteligencji. LRU walczył o narodowo-demokratyczne duchowe odrodzenie Ukrainy. W październiku 1989 roku założyciele tej organizacji precyzyjnie zadeklarowali swoją walkę o wprowadzenie systemu multipartyjnego, autonomię gospodarczą oraz suwerenność republiki. Pierwszą próbą dla LRU stały się wybory parlamentarne w marcu 1990 roku. Należy zaznaczyć, iż wybory te były częściowo wolne. W ich rezultacie Blok Demokratyczny (składający się z nieformalnych ugrupowań opozycyjnych) uzyskał $25 \%$ miejsc w parlamencie. W 1990 roku odbyło się wiele akcji politycznych, między innymi 21 stycznia aktywiści utworzyli 
żywy łańcuch symbolizujący połączenie ZUNR i UNR. Z kolei w dniach 2-17 października miała miejsce „Rewolucja na granicie”, podczas której studenci wygłosili wiele politycznych postulatów ${ }^{31}$.

Jak zaznacza Beata Surmacz, dla ukraińskich środowisk demokratycznych inspiracją była polska „Solidarność”, o czym świadczy na przykład udział polskich polityków Bogdana Borusewicza, Adama Michnika, Włodzimierza Mokrego podczas zjazdu założycielskiego Ludowego Ruchu Ukrainy ${ }^{32}$. Jednak należy podkreślić, iż ruch opozycyjny w tym okresie nie głosił haseł niepodległościowych, a społeczeństwo nie było gotowe do takich radykalnych metod przekształceń ustrojowych. Opozycja nie miała masowego poparcia wśród wszystkich warstw społecznych, dlatego nie udało się zorganizować protestu na szeroką skalę na rzecz niepodległości Ukrainy.

Dnia 16 lipca 1990 roku Rada Najwyższa USRR ogłosiła deklarację suwerenności, w wyniku której już odważniej wykonywała swoje funkcje legislacyjne. Natomiast kiedy 19 sierpnia 1991 roku dokonał się pucz Giennadija Janajewa zorganizowany przez „twardogłowych” liderów KPZR, Rada Najwyższa wybrała strategię wyczekiwania. Tylko narodowo-patriotyczne siły w parlamencie zdecydowanie potępiały działania Państwowego Komitetu Stanu Nadzwyczajnego. Po klęsce puczu republiki związkowe zaczęły wygłaszać akty niepodległości. Przedterminowe obrady Rady Najwyższej URSS odbyły się 24 sierpnia 1991 roku, kiedy został uchwalony Akt Niepodległości Ukrainy. 1 grudnia 1991 roku zorganizowano referendum ogólnokrajowe, w którym miał być przyjęty lub odrzucony przez ludność republiki akt o niepodległości państwa. W referendum wzięło udział więcej niż 85\% ludności, na „tak” zagłosowało 90\% wyborców. W tym samym dniu odbyły się pierwsze wybory prezydenckie, w których zwyciężył Leonid Krawczuk (od 1958 r. był członkiem KPZR.) Krawczuk wygrał z działaczem opozycyjnego Ruchu, Wiaczesławem Czornowiłem, uzyskując ponad $61 \%$ poparcia $^{33}$.

Dojście do władzy starej komunistycznej nomenklatury na Ukrainie na długi czas wyznaczyło charakter demokratycznej transformacji. Jak zaznacza Antonina Kolodii, ,opozycja antykomunistyczna nie zdołała zdobyć władzy zarówno podczas ogłoszenia niepodległości przez Ukrainę, jak i w późniejszym okresie rozwoju państwa. Oznaczało to, iż reformy demokratyczne były przeprowadzane przez tych, którzy nie byli nimi zainteresowani, a mianowicie przez część elity starej nomenklatury. Przedstawiciele tej elity odgrywali rolę demo-

31 Ibidem, s. 131.

32 B. Surmacz: Współczesne stosunki polsko-ukraińskie. Politologiczna analiza traktatu o dobrym sąsiedztwie. Lublin 2002, s. 36.

33 We wszystkich 27 regionach wyborcy wsparli akt o ogłoszeniu niepodległości z dnia 24 sierpnia 1991 r. Najmniejsze poparcie było na Krymie (54,2\%), największe — w obwodzie tarnopolskim (98,7\%). W Donbasie wyborcy także poparli niezależność Ukrainy — na „tak” zagłosowało ponad 83\% (obwody ługański i doniecki). 
kratyzatorów w zależności od uwarunkowań, ponieważ chcieli dostosować się do nowych warunków życia politycznego i zachować swoje władne pozycje" ${ }^{34}$. Jak zaznacza Roman Oficyńskyj, w 1996 roku w nowych organach władzy pracowało jeszcze $75 \%$ starej komunistycznej nomenklatury. Odpowiednio wytworzyła się „szara strefa” pomiędzy polityką a biznesem, najważniejsze decyzje podejmowano w kulisach władzy przez jej byłych oraz ówczesnych aktorów ${ }^{35}$. Stara nomenklatura ukształtowała większość w parlamencie, a także stanęła u steru wszystkich dziedzin życia, faktycznie przyczyniła się do pojawienia się polityczno-ekonomicznych grup interesu (oligarchów), którzy do dnia dzisiejszego wywierają wpływ na politykę w państwie.

$\mathrm{Na}$ Ukrainie demokratyczna opozycja w okresie przejściowym nie miała masowego wsparcia we wszystkich regionach państwa. W latach 1991-2000 nie było rzeczywistej opozycji politycznej wobec władzy. Jak zaznacza badaczka Liana Hurska-Kowalczyk, ,pojawiła się jedynie opozycja sytuacyjna, wariantami której były: opozycja dekoracyjna (Komunistyczna Partia Ukrainy) i »konstruktywna« (Ruch Ludowy Ukrainy na czele z W. Czornowiłem)"36. Tragicznym wydarzeniem dla ukraińskiej opozycji była śmierć jedynego lidera opozycyjnego Wiaczesława Czornowiła podczas wypadku w ,nieustalonych” do dnia dzisiejszego okolicznościach ${ }^{37}$. To fatalne wydarzenie faktycznie odsunęło w czasie konsolidację ukraińskiej opozycji aż na pięć lat. Jednocześnie brak silnej opozycji był uwarunkowany ówczesnym stanem kultury politycznej społeczeństwa. W latach dziewięćdziesiątych przeważała warstwa ludzi biednych (od 75\% do $80 \%$ ), która była niejednorodna ze względu na strukturę zawodową i status społeczny. Była to warstwa ludzi obojętnych wobec polityki, walczących z ubóstwem. Również z powodu braku rozwiniętej klasy średniej kształtowanie się systemu partyjnego dokonywało się „z góry”, było narzucane społeczeństwu przez elity rządzące. Jako że zmianom systemu politycznego od początku lat dziewięćdziesiątych nie towarzyszyła wymiana elit politycznych, u steru pozostała stara elita, która wywodziła się z nomenklatury radzieckiej.

W okresie niepodległości Ukrainy nastąpiła ewolucja kultury politycznej społeczeństwa obywatelskiego, które coraz częściej zaczynało wywierać wpływ na funkcjonowanie instytucji politycznych. W sytuacji, gdy państwo zmierzało

${ }^{34}$ A. KoloDII: Trajektoria demokratycznego przejścia na Ukrainie. W: Transformacja w Polsce i na Ukrainie. Wybrane aspekty. Red. A. Antoszewski, A. Kolodi, K. KowalCZYK. Wrocław 2010, s. 23.

35 R. Oficyns'Kis: Politycznyjj rozwitok nezależnoj Ukrainy (1991-2004) w aspekti ewropejs'koj identycznosti. Użgorod 2005, s. 160. s. 139.

${ }^{36}$ L. Hurska-KowalczyK: Opozycja polityczna na Ukrainie 1991-2006. Toruń 2011,

${ }^{37}$ Ricznica smerti Wiaczeslawa Czornowola: ukrainci wymagajut' znajty wynnych https://uain.press/articles/richnytsya-smerti-v-yacheslava-chornovola-ukrayintsi-vymagayutznajty-vynnyh-765112 (dostęp: 20.10.2018). 
do autorytaryzmu, miały miejsce pomarańczowa rewolucja i rewolucja godności. W taki sposób społeczeństwo obywatelskie poprzez swój protest zmieniło kierunek transformacji Ukrainy na demokratyczny. Jednak należy zaznaczyć, iż to właśnie z powodu bierności społecznej w latach dziewięćdziesiątych XX wieku stara nomenklatura pozostała u władzy i sprzyjała działaniom oligarchów, którzy do dnia dzisiejszego pozostają jedną z przeszkód na drodze ku skonsolidowanej demokracji. Postradziecka polityczna kultura elit rządzących sprawia, iż transformacja odbywa się wolniej, niż tego oczekują obywatele, a polityka Wiktora Janukowycza przyczyniła się do ustanowienia autorytaryzmu. Odpowiednio, dokonując rewolucji godności, społeczeństwo powinno nadal wywierać aktywną presję na polityków w celu kontroli ich działalności oraz realizacji dalszych reform.

\section{Polityka elit rządzących}

Kluczową determinantą wywierającą wpływ na tempo procesu transformacji demokratycznej w obu państwach jest zachowanie elit rządzących. Odegrały one szczególną rolę w początkowej fazie przemian systemowych, kiedy budowano instytucjonalne podstawy państwa, a także wprowadzano demokratyczne procedury. Rola elit politycznych w okresie przejściowym zasadniczo się różni w analizowanych państwach. Jeżeli w Polsce szybko został wprowadzony scenariusz reform demokratycznych, to na Ukrainie zamiast realizacji reform spostrzegamy ciągłą walkę o władzę.

Elity rządzące w Polsce i na Ukrainie w różny sposób podchodziły do kwestii uchwalenia konstytucji. Proces konstytucyjny w obu państwach istotnie się różni — w Polsce zakończył się on uchwaleniem Konstytucji w 1997 roku, natomiast na Ukrainie trwa do dnia dzisiejszego i stał się instrumentem realizacji partykularnych celów aktorów politycznych.

Polska na początkowym etapie transformacji systemowej napotykała wiele wyzwań związanych z efektywnością rządzenia. W latach 1990-1991 reżim polityczny odznaczał się autorytarnym stylem rządzenia prezydenta Wałęsy. W okresie przed wyborami prezydenckimi w 1990 roku egzekutywa potrafiła wzmocnić swoją pozycję względem legislatywy w ramach istniejącego modelu reżimu politycznego. Napięcia między naczelnymi organami władzy państwowej trwały również po wyborach w październiku 1991 roku. Prezydent i koalicja sejmowa próbowali stworzyć swój preferowany rząd, dlatego okres formowania rządu wydłużył się do dwóch miesięcy. Konflikty na linii prezydent — rząd - sejm ciągle wybuchały, co spowodowało obniżenie poparcia społecznego dla tych instytucji. Były liczne przypadki przekroczenia przez pre- 
zydenta i sejm swoich kompetencji, wyznaczonych konstytucją. Jednak polscy badacze zaznaczają, iż wniosek o rażącym naruszeniu przepisów przez Wałęsę jest zbyt daleko idący. Analizując funkcjonowanie instytucji prezydenta w okresie kadencji Wałęsy, Jerzy Wiatr zaznacza, iż „w początkowym etapie L. Wałęsa nie był typowym autokratą, dążącym do dyktatury. Nie był również przywódcą w pełni demokratycznym, szanującym przeciwnika, gotowym do dialogu, traktującym normy konstytucyjne jako niepodważalne" ${ }^{38}$. Robert Glajcar zauważa, iż Wałęsa często postępował ponad procedurami, jednak pomimo prób pozakonstytucyjnego poszerzenia zakresu swoich uprawnień, nie udało mu się przejąć roli szefa egzekutywy ${ }^{39}$. Następny prezydent Aleksander Kwaśniewski potrafił współpracować z przeciwnikami politycznymi, nie wywoływał konfliktów oraz był skuteczny w osiąganiu swoich celów.

Nie zważając na kryzys konstytucyjny w pierwszych latach niepodległości, Polsce udało uchwalić Małą Konstytucję z dnia 17 października 1992 roku, w której została wprowadzona zasada trójpodziału władzy. Jak pokazała praktyka polityczna, Mała Konstytucja zawierała wiele nieprecyzyjnych przepisów, które były różnie interpretowane przez naczelne organy władzy państwowej. Cechą charakterystyczną późniejszego etapu prezydentury Wałęsy było zjawisko „falandyzacji prawa”, polegające na nieprecyzyjności przepisów, które pozostawiały prezydentowi szerokie pole manewru ${ }^{40}$. Dlatego powstała konieczność udoskonalenia tego dokumentu, czego dokonano później — 2 kwietnia 1997 roku uchwalono Konstytucję RP.

Polscy badacze zaznaczają, iż wzorzec reżimu politycznego zaproponowany przez Konstytucję RP z 1997 roku zazwyczaj był przestrzegany przez główne organy władzy państwowej. Dokonując analizy funkcjonowania reżimu politycznego, Glajcar wnioskuje, iż w latach 1997-2015 w zakresie powołania rządów nie nastąpiło zasadnicze odchylenie od konstytucyjnego wzorca. Jedynie w przypadku tworzenia rządu Marka Belki konstytucyjny wzorzec reżimu politycznego został nieco skorygowany — można było zaobserwować znaczący wpływ prezydenta na kształtowanie politycznego i personalnego składu Rady Ministrów ${ }^{41}$.

W polskim modelu reżimu politycznego wprowadzonym przez Konstytucję z 1997 roku premier odgrywa rolę najważniejszej postaci na krajowej scenie politycznej. W kontekście relacji pomiędzy premierem a prezydentem w latach 1997—2010 doszło do wielu sporów w obrębie egzekutywy. Relacje pomiędzy

38 J. Wiatr: Pięć parlamentów III Rzeczpospolitej. W: Demokracja Polska 1989-2003. Red. J. Wiatr, J. Raciborski, J. Bartkowski, B. Frączak-Rudnicka. Warszawa 2003, s. 106.

39 R. GlajCar: Demokratyczny reżim polityczny. Relacje między legislatywa i egzekutywa w III Rzeczypospolitej. Katowice 2015, s. 460.

40 Ibidem, s. 354.

${ }^{41}$ Ibidem, s. 491. 
prezydentem a premierem analizuje Andrzej Antoszewski, zaznaczając, iż lata 1997-2001 charakteryzowała „niechętna neutralność”, lata 2001-2005 — „szorstka przyjaźń”, lata 2005—2007 — „idylliczna współpraca”, a lata 2007— 2010 - „otwarty konflikt”42. Ciąg ten kontynuuje Glajcar, określając lata 2010 - 2015 - mianem ,wzajemnej sympatii” w relacjach między prezydentem a premierem. Jednak istniejące konflikty $\mathrm{w}$ relacjach między prezydentem a rządem nie wpłynęły na kształt reżimu politycznego, nie została także zakwestionowana zasada, według której premier jest formalnym i faktycznym szefem egzekutywy ${ }^{43}$.

Rok 2015 przyniósł zmiany w praktyce funkcjonowania polskiego reżimu politycznego. Od 2006 roku istniała tradycja, zgodnie z którą na czele rządów stali szefowie partii. Natomiast obecnie urząd premiera sprawuje nie lider partyjny, lecz polityk tzw. drugiego planu. Jak pokazała praktyka, najważniejsze decyzje polityczne są podejmowane nie w obrębie naczelnych organów władzy państwowej (premier i prezydent), lecz przez prezesa PiS - Jarosława Kaczyńskiego. Taka sytuacja, jak zaznaczają badacze Małgorzata Lorencka, Małgorzata Myśliwiec, Waldemar Wojtasik, spowodowała odejście od konstytucyjnego wzorca reżimu politycznego, ponieważ prawdziwa siła instytucji premiera i prezydenta jest słabsza, niż jest to przewidziane w Konstytucji. Autorzy zaznaczają, iż takie tendencje mogą doprowadzić do marginalizacji systemu partyjnego i procedury wyborczej, degradacji systemowej roli politycznych partii, co niewątpliwie negatywnie zaznaczy się na demokracji w Polsce ${ }^{44}$.

$\mathrm{W}$ dniu dzisiejszym istnieje wiele propozycji optymalizacji ustroju konstytucyjnego Polski. Niektórzy badacze uważają, iż koncepcja trójpodziału władzy jest realizowana niekonsekwentnie, w rezultacie czego mamy do czynienia z praktyką dryfowania w kierunku supremacji władzy ustawodawczej ${ }^{45}$. Natomiast istnieją także odmienne opinie, według których rozwiązania wprowadzone przez Konstytucję z 1997 roku się sprawdziły ${ }^{46}$. Taki wniosek w zasadzie jest potwierdzeniem tego, iż dotychczas nie została uchwalona żadna nowa redakcja ustawy zasadniczej.

$\mathrm{Na}$ Ukrainie w kwestii Konstytucji 1996 roku, wprowadzającej system prezydencko-parlamentarny, prezydent mianuje i dymisjonuje premiera za zgo-

42 A. Antoszewski: System polityczny RP. Warszawa 2012, s. 87.

${ }^{43}$ R. GlajCaR: Demokratyczny rezim polityczny..., s. 468.

${ }^{44}$ M. Lorencka, M. Mrśliwiec, W. Wojtasik: Evolution of the Political System in Poland after 1989. In: Democratization processes in Poland and Slovenia. Comparative Study. Eds. A. Turska-Kawa, M. HačeK. Maribor 2016, s. 73.

${ }^{45}$ R. Grabowski: Zasady podziatu władzy w Polsce. W: Zasady podziatu władzy we współczesnych państwach europejskich. Red. S. Grabowska, R. Grabowski. Rzeszów 2016, s. 242.

46 J. JASKieRnia: System rządów w Rzeczypospolitej Polskiej w świetle aktualnych propozycji jego zmian. „Przegląd Prawa Konstytucyjnego” 2012, nr 2(10), s. 125. 
dą parlamentu, na wniosek premiera powołuje członków Gabinetu Ministrów oraz tworzy, reorganizuje, likwiduje ministerstwa. W rzeczywistości premier był całkowicie zależny od woli prezydenta, natomiast w praktyce kandydatury wicepremierów, ministrów, przewodniczących komitetów państwowych były zgłaszane nie przez premiera, a przez Administrację Prezydenta, która stała się nieformalnym ośrodkiem podejmowania decyzji.

Należy zaznaczyć, iż ustawodawca na Ukrainie wprowadził nieprzemyślane mechanizmy „hamulców i równoważeń”, które nie sprawdziły się w kontekście sytuacyjnym ze względu na niedemokratyczną kulturę polityczną elity rządzącej. Prezydent według zapisów Konstytucji z 1996 roku posiadał na tyle szerokie kompetencje, iż zapisy mające odgrywać rolę mechanizmów zapobiegających uzurpacji przez niego władzy wykonawczej okazały się nieefektywne. Chodzi między innymi o:

- desygnowanie przewodniczących lokalnych organów administracji państwowych jedynie na wniosek Gabinetu Ministrów (art. 118);

- desygnowanie przewodniczących centralnych organów administracji państwowej na wniosek premiera Ukrainy (art. 106);

— posiadanie przez Gabinet Ministrów możliwości kontrasygnaty aktów głowy państwa (art. 106) ${ }^{47}$.

W warunkach, gdy ich dymisja całkowicie zależała od prezydenta, urzędnicy w systemie władzy wykonawczej nie wykazywali inicjatywy do wykorzystywania zapisów konstytucji w celu wywierania wpływu na decyzje prezydenta, nawet wtedy, kiedy zapisy prawne były oczywiste. W konsekwencji prezydent Kuczma w okresie swojej prezydentury w latach 1994-2004 wybudował scentralizowany pion władzy wykonawczej oraz skoncentrował ją w swoich rękach.

Wymowny jest też fakt częstej zmiany premiera, którego zgodnie z Konstytucją 1996 roku mianował prezydent. W latach 1994-1995 był to Witalij Masoł, w 1995-1996 - Jewhen Marczuk, w 1996-1997 — Pawło Łazarenko, w 1997-1999 - Wałerij Pustowojtenko, w 1999-2001 — Wiktor Juszczenko, w 2001 - 2002 Anatolij Kinach, a w 2002-2005 — Wiktor Janukowycz. Wszyscy premierzy byli zdymisjonowani przez prezydenta i tylko jeden premier, Juszczenko, został zdymisjonowany poprzez uchwalenie większością „proprezydencką" rezolucji nieufności, ponieważ w tej sytuacji parlament i prezydent mieli wspólne motywy działania.

W kwestii działalności rządu i jego odpowiedzialności możemy stwierdzić, iż na Ukrainie Gabinet Ministrów w okresie prezydentury Kuczmy został faktycznie zastąpiony przez Administrację Prezydenta, która formalnie nie była według Konstytucji z 1996 roku osobnym podmiotem władzy państwowej i nie posiadała żadnych własnych uprawnień, miała jedynie realizować działa-

${ }^{47}$ Antologija konstitucyjnogo procesu w suczasnij Ukraini. Centr Razumwoka. Kyiw 2017, s. 83. 
nia głowy państwa na wielu płaszczyznach ${ }^{48}$. W praktyce politycznej Administracja Prezydenta zaczęła wykraczać poza powierzone jej zadania, stając się nieformalnym ośrodkiem podejmowania decyzji i przejmując kompetencję rządu ${ }^{49}$. Należy również podkreślić, iż skład personalny Administracji Prezydenta w większości tworzyła stara nomenklatura radziecka. Wartym uwagi jest fakt, iż Wiktor Medwedczuk, szef Administracji Prezydenta w latach 2002 - 2004, przyczynił się do tragicznego losu ukraińskiego poety — Wasyla Stusa (zginął 4 września 1985 r.), który jest symbolem narodowym dla wielu Ukraińców. Uczestnik ukraińskiego opozycyjnego ruchu odbywał karę trzech lata pozbawienia wolności w kolonii srogiego reżimu za antyradziecką agitację i propagandę. W swoim ostatnim słowie 17 grudnia 1979 roku poeta szczególnie podkreślał bierność swojego adwokata, Medwedczuka, która była uwarunkowana poleceniami wydawanymi z góry ${ }^{50}$. Kwestia ta znalazła szeroki rezonans na Ukrainie w 2018 roku, kiedy to wybuchł skandal dotyczący produkcji filmu o dysydencie z czasów ZSRR Wasylu Stusie. Film miał zawierać sceny przedstawiające wpływ adwokata, Medwedczuka, na życie poety. Według mediów producenci chcieli zrezygnować z postaci adwokata w scenariuszu po ostrzegawczych telefonach z jego biura. Sytuacja ta wywołała falę krytyki w ukraińskiej opinii publicznej ${ }^{51}$.

Konstytucja z 1996 roku nie wyznacza precyzyjnych mechanizmów odpowiedzialności rządu przed parlamentem. Jedynie art. 87 UZ mówi o możliwości uchwalenia rezolucji nieufności wobec rządu przez większość konstytucyjną składu parlamentu na wniosek nie mniej niż 1/3 parlamentu (wniosek taki mógł być złożony tylko jeden raz w ciągu jednej sesji), czyli prezydent Kuczma stał się faktycznie jedynym centrum podejmowania decyzji w obrębie władzy wykonawczej.

Uchwalenie redakcji Konstytucji z 2004 roku zbalansowało trójpodział władzy - ograniczyło władzę prezydenta, nadało większe pełnomocnictwa władzy ustawodawczej oraz po raz pierwszy wprowadziło nową instytucję polityczną — koalicję większościową. Jednak uchwalenie tego dokumentu nie powstrzymało aktorów politycznych od rywalizacji o władzę. Okres 2004-2010 charakteryzował się politycznym chaosem, spowodowanym częstymi konfliktami w „obozie pomarańczowym”, długimi przetargami dotyczącymi powołania koalicji, polityczną korupcją (przekupienie przez Partię Regionów Socjalistycz-

48 A. Olechno: Instytucja Prezydenta $w$ systemie konstytucyjnych organów Ukrainy. Toruń 2009, s. 200. R. Oficyns'Kis: Politycznyjj rozwitok nezależnoj Ukrainy..., s. 175.

49 Antologija konstitucyjnogo procesu..., s. 83.

${ }^{50}$ R. Oficyns'KiJ: Politycznyjj rozwitok nezależnoj Ukrainy..., s. 175.

${ }_{51}$ Znimalna grupa filmu ,Stus” obicaje powernuty do kartyny scenu sudylyszcza za uczastiu Medwedczuka —https://espreso.tv/news/2018/08/11/znimalna_grupa_filmu_quotstusquot_obicyaye_povernuty_do_kartyny_scenu_sudylyscha_za_uchastyu_medvedchuka (dostęp: 22.10.2018). 
nej Partii Ukrainy — według niepotwierdzonych informacji oferowano $300 \mathrm{mln}$ USD za podpisanie utworzenia koalicji) ${ }^{52}$. Wszystko to doprowadziło do zmiany władzy.

Od 2010 roku prezydent Janukowycz bardzo szybko zaczął odbudowywać pion władzy, który został zniesiony podczas prezydentury Juszczenki. Zdobywając kontrolę nad władzą ustawodawczą, Janukowycz dokonał faktycznego przewrotu konstytucyjnego, kiedy 30 września 2010 roku z jego inicjatywy Sąd Konstytucyjny unieważnił swoje poprzednie orzeczenie (twierdząc, iż było ono niezgodne z Konstytucją), na mocy którego w państwie już od ponad pięciu lat obowiązywał system parlamentarno-prezydencki. Sąd Konstytucyjny przywrócił moc Konstytucji z 1996 roku. Kolejnym wykroczeniem prezydenta był osobisty wpływ na parlament, w wyniku czego 16 stycznia 2014 roku zostały uchwalone „Drakońskie ustawy” z poważnymi naruszeniami przepisów konstytucji. Ustawy naruszały podstawowe wolności obywateli oraz zasadę rządów prawa, wprowadzając $w$ państwie autorytaryzm. Niedemokratyczny styl rządzenia Janukowycza oraz jego rezygnacja z podpisywania Umowy Stowarzyszeniowej z UE stały się jedną z przyczyn rewolucji godności. Należy nadmienić, iż rewolucja wznowiła prodemokratyczny kierunek transformacji na Ukrainie. Została przywrócona redakcja Konstytucji 2004 roku, wprowadzająca system parlamentarno-prezydencki. Jednak możemy zaważyć, iż nieformalna praktyka elit rządzących niezgodna z zasadami demokratycznych rządów prawa nie zniknęła do dnia dzisiejszego. Świadczy o tym na przykład przekupywanie deputowanych przez partię Blok Petra Poroszenki w celu głosowania na poszczególne projekty ustaw. W taki sposób została przegłosowana w pierwszym czytaniu Ustawa o wprowadzeniu zmian do Konstytucji dotyczących decentralizacji władzy dotycząca szczególnego statusu Donbasu, która spotkała się z ostrą krytyką opinii publicznej ${ }^{53}$.

W okresie przejściowym przed państwem stoi wiele zadań z zakresu wyboru odpowiednich rozwiązań instytucjonalnych. Priorytetową kwestią w tym zakresie jest kształtowanie systemu wyborczego, który stanowi jedną z najbardziej istotnych determinant systemu partyjnego. Jak niejednokrotnie zaznaczają politolodzy, zinstytucjonalizowany system partyjny to nieodłączny warunek skonsolidowanej demokracji. Należy zaznaczyć, iż systemy partyjne w państwach pokomunistycznych charakteryzują się niestabilnością, ponieważ proces ich kształtowania istotnie odróżnia się od tych, które istnieją w starych demokracjach (najwyraźniej tłumaczy to podejście tabula rasa) ${ }^{54}$.

52 W. BaluK: Koalicje gabinetowe na Ukrainie w latach 2002-2012. Lublin 2012, s. 152.

53 Postanowa Werchownoj Rady Ukrainy „Pro poperedne schwalennia zakonoproektu pro wnesennia zmin do Konstytucyi Ukrainy szczodo decentralizacyi wlady" — http:// zakon2.rada.gov.ua/laws/show/656-19 (dostęp: 30.06.2018).

${ }^{54}$ J. Bielasiak: The Institutionalization of Electoral and Party Systems in Postcommunist States. "Comparative Politics" 2002, Vol. 34, No 2, s. 189. 
Po ogłoszeniu niepodległości Ukraina w porównaniu do swoich sąsiadów państw będących członkami Unii Europejskiej - nie potrafiła stworzyć odpowiednich warunków do efektywnego funkcjonowania partii politycznych oraz instytucjonalizacji systemu partyjnego. System partyjny Ukrainy pozostaje nadal niezinstytucjonalizowany oraz zależny od wahań transformacji systemowej - to w stronę demokracji, to w stronę autorytaryzmu ${ }^{55}$. Do takiego stanu rzeczy przyczyniły się w dużym stopniu elity rządzące, które nie potrafiły w początkowej fazie transformacji demokratycznej stworzyć efektywnych oraz przemyślanych zasad prawnych sprzyjających instytucjonalizacji partii politycznych na Ukrainie.

Wśród czynników, które wpłynęły na słabą instytucjonalizację systemu partyjnego na Ukrainie należy wskazać częste zmiany systemu wyborczego. Na Ukrainie przetestowano wszystkie trzy typy systemów wyborczych w okresie niepodległości. Pierwsze wybory parlamentarne 1994 roku były przeprowadzone według ordynacji większościowej, drugie i trzecie (lata 1998 i 2002) — według ordynacji mieszanej, w czwartych (2006 r.) i piątych (2007 r.) obowiązywała ordynacja proporcjonalna, a w latach 2012 i 2014 wybory odbyły się według ordynacji mieszanej. Ciągle zmieniający się system wyborczy na Ukrainie implikował radykalne zmiany w „regułach gry” co osiem lat, co z kolei stało się przeszkodą w instytucjonalizacji systemu partyjnego. Należy zaznaczyć, iż we wszystkich wyborach parlamentarnych zarówno dla partii, jak i bloków wyborczych stosowany był ten sam próg wyborczy. Doprowadziło to do typowego zjawiska „imiennych” bloków na ukraińskiej scenie partyjnej, które stały się celem samym w sobie - zaczęły służyć jako instrument wygrania wyborów parlamentarnych. Zamiana partii politycznych jako podmiotu procesu wyborczego na bloki wyborcze, których skład często jest modyfikowany i które również znikają ze sceny partyjnej, doprowadziła do deformacji i degradacji systemu partyjnego na Ukrainie.

Charakterystyczna dla państw postkomunistycznych jest nieufność społeczeństw do partii politycznych. Ukraina w tym kontekście nie jest wyjątkiem. Natomiast na przestrzeni dwudziestu pięciu lat niepodległości elity polityczne nie zrobiły nic, aby to zaufanie poprawić. Nieprzemyślane i często zmieniające się regulacje prawne, korupcja polityczna, populizm oraz niewykonywanie swoich obietnic sprawiły, iż chwiejność wyborcza na Ukrainie jest bardzo wysoka ${ }^{56}$.

Polski system partyjny również charakteryzował się chwiejnością w początkowym etapie demokratyzacji państwa. W latach 1991—2001 polską scenę polityczną również cechowała niestabilność, wiązało się to z niskim poziomem

55 O. RyвiY: Party System Institutionalization in Ukraine. „Democratizatsiya” 2013, No 21, s. 422, https://www2.gwu.edu/ ieresgwu/assets/docs/demokratizatsiya\%20archive/GWAS HU_DEMO_21_3/T8250N71P44Q0H47/T8250N71P44Q0H47.pdf, (dostęp: 15.10.2018).

${ }^{56}$ Ibidem, s. 411. 
instytucjonalizacji politycznej. Przyczyną tego były częste zmiany elektoralnych regulacji. W Polsce podobnie - miała miejsce praktyka kształtowania ordynacji wyborczej pod kątem realizacji indywidualnych celów elit rządzących, ale w porównaniu z Ukrainą ordynacja wyborcza nie zmieniała się tak drastycznie. W 1989 roku była zastosowana większościowa ordynacja wyborcza, a od 1991 roku - obowiązywała ordynacja proporcjonalna. Natomiast znaczący wpływ na kształtowanie systemu partyjnego wywarły przede wszystkim zmiany metody sposobu liczenia. W 1991 roku obowiązywała metoda zmodyfikowana Sainte-Laguë, w latach 1993 i 1997 — metoda d'Hondta, w 2001 roku — zmodyfikowana metoda Sainte-Laguë, a w latach 20052015 — ponownie metoda d'Hondta. Należy zwrócić uwagę na to, iż w 1993 roku została wprowadzona klauzula zaporowa $5 \%$ dla partii politycznych oraz $8 \%$ dla koalicji. Po okresie zmian w systemie wyborczym w latach dziewięćdziesiątych XX wieku reguły elektoralne ustabilizowały się dopiero w 2005 roku. Należy przyznać, iż system wyborczy, pomimo wpływu innych czynników, przyczynił się do instytucjonalizacji systemu partyjnego ${ }^{57}$. Natomiast, jak zaznacza Antoszewski, system partyjny na koniec pierwszej dekady XXI wieku pozostaje wciąż „,kruchy” i ,wrażliwy", czego przyczyną jest wysoki poziom chwiejności wyborczej oraz niski poziom frekwencji ${ }^{58}$. Wybory parlamentarne 2015 roku pokazały, iż na scenę partyjną coraz częściej wkraczają partie antysystemowe (Kukiz'15), które odzwierciedlają społeczne niezadowolenie z funkcjonowania głównych instytucji demokratycznych.

Transformacja gospodarcza w obu państwach odbywała się w trudnych i niekorzystnych warunkach, które zostały odziedziczone po okresie przedtransformacyjnym. W 1989 roku Polska zaczynała transformację gospodarczą w złożonej sytuacji - gigantycznej inflacji, obciążeń długami zagranicznymi, znaczącej nierównowagi rynkowej i niskiego poziomu zaspokojenia potrzeb mieszkańców. Jednak dzięki determinacji elit politycznych udało się dokonać radykalnych i natychmiastowych reform gospodarczych. Dzięki takiemu wdrożeniu zmian możliwy stał się postęp w kierunku wolności gospodarczej. W rezultacie Polska osiągnęła największy sukces wśród krajów wychodzących z socjalizmu. Należy zaznaczyć, iż pomyślności reform sprzyjała liberalizacja w sferze gospodarki u progu transformacji.

W porównaniu do państw Europy Środkowej i Wschodniej na większości terytorium Ukrainy (oprócz zachodnich regionów) własność prywatna była całkowicie zniszczona. Nawyki prowadzenia biznesu prywatnego były tak słabe, iż trzeba było zaczynać od podstaw. Taka sytuacja spowodowała zależność transformacji gospodarczej od polityki elit i jej kierunku reform. Wolny roz-

${ }^{57}$ M. Lorencka, M. Myśliwiec, W. Wojtasik: Evolution of the Political System in Poland..., s. 72.

58 A. Antoszewski: System polityczny RP. Warszawa 2012, s. 296. 
wój ekonomiczny był faktycznie rezultatem niezdolności i niechęci starej elity do realizacji transformacji gospodarczej. Prezydenci Kuczma i Krawczuk, będąc przedstawicielami starej nomenklatury radzieckiej, wybrali rosyjski model reform gospodarczych. Transformacja zaczynała się bez opracowanych celów i strategii dostosowanych do specyficznych realiów państwa. W rezultacie zamiast wolnorynkowej gospodarki ukształtowała się „szara strefa” pomiędzy biznesem a polityką ${ }^{59}$. Pojawiło się kilka polityczno-ekonomicznych klanów: doniecki, kijowski, dniepropietrowski i charkowski. Potęga tych grup bazuje na bliskości i współpracy z elitami rządzącymi oraz na możliwości ich wpływu na podejmowanie decyzji politycznych. Jak zaznacza Ołeksij Chmara, ekspert Transparency International Ukraine, „niepodpisanie umowy stowarzyszeniowej z UE przez W. Janukowycza, świadczyło o strachu oligarchów przed przejrzystą konkurencją. Ukraińscy monopoliści nie byli chętni do prowadzenia biznesu według zasad wolnorynkowych. Dlatego wybrali znane mechanizmy współpracy ze skorumpowanymi sąsiadami" "60.

Przyczyn efektywności lub porażki procesu demokratyzacji w obu państwach należy doszukiwać się w kulturze politycznej i prawnej elit rządzących. Istotny wydaje się fakt, iż każdy obóz rządzący w Polsce kontynuował demokratyczne reformy. Należy zwrócić uwagę na to, że żadna z partii, która kiedykolwiek uzyskała poparcie powyżej $2 \%$, nie nawoływała do restytucji systemu radzieckiego. Ideowe oblicza elit rządzących w Polsce i na Ukrainie zasadniczo się różnią. Należy zaznaczyć, iż w Polsce po 1989 roku nie pojawiła się żadna znacząca siła polityczna kwestionująca ogólny kierunek transformacji. Wyniki wyborów do Sejmu w latach 1991 i 1993 wskazują, iż poparcie społeczne dla partii deklarujących demokratyczny rozwój państwa zdecydowanie przeważa. W 1993 roku, kiedy SLD zdobyło władzę w wyborach parlamentarnych i utworzyło koalicję, formacja ta nie nawoływała do ścisłej współpracy z Rosją, a jej retoryka była wyraźnie prozachodnia ${ }^{61}$. Partia SLD genetycznie była powiązana z okresem PRL-u, tak jak wywodziła się z reformatorskiego skrzydła byłej partii komunistycznej. Partia ta w wyborach w 1993 roku zaczęła budować swoją pozycję jako formacja nawiązująca do typowych socjaldemokracji zachodnioeuropejskich. SLD w swoich kampaniach wyborczych starało się pozbyć ciężaru przeszłości. Kwaśniewski, który pochodził z ramienia centrolewicowej SLD,

59 W. Lanowys: Skromna czariwnist' oligarchii. Ekonomiczna prawda, 26 listopada 2013 - https://www.epravda.com.ua/publications/2013/11/26/405262/?fbclid=IwAR0PtPd2 yd5-t3Vh-tq3yucjOnEQ4_EN5uBGK21LmmKv3HTT3QRQsQBgnyc (dostęp: 20.08.2018).

${ }^{60}$ Transparency International: korumpowani oligarchiczni klany wbiwajut' w Ukraini czesnyj biznes. ZN.UA, 3 grudnia 2013 roku - https:/dt.ua/ECONOMICS/transparencyinternational-korumpovani-oligarhichni-klani-vbivayut-v-ukrayini-chesniy-biznes-133087. html?fbclid=IwARlyg-zypymPRckpxVy-Qwwfacauem71Hymz22iXWMivI58Ed1J4mRi2n So (dostęp: 20.08.2018).

${ }^{61}$ M. Migalski: Czeski i polski system partyjny. Warszawa 2008, s. 221. 
w czasie swojej prezydentury odznaczył się efektywną, niekonfliktową współpracą z innymi naczelnymi organami władzy państwowej. W czasie jego prezydentury Polska otrzymała zaproszenie do NATO, przeprowadzono referendum konstytucyjne, a sytuacja gospodarcza się poprawiała. Należy też zwrócić uwagę na fakt, iż w 2001 roku partia ta odeszła od roli typowej socjaldemokracji, zajmując centralną pozycję w wymiarze prawica - lewica.

KPU na Ukrainie natomiast orientowała się na grupy żyjące według ideologii radzieckiej. Jak zaznacza Hurska-Kowalczyk, komuniści ukraińscy w przeciwieństwie do byłych partii komunistycznych Europy Środkowej nie potrafili transformować swoich zasad ideologiczno-programowych po rozpadzie ZSRR ${ }^{62}$. Autorka odnosi KPU do formacji antypaństwowej z elementami antysystemowymi. Założenia programowe opierały się na ideologii marksizmu-leninizmu i doświadczeniu „bolszewików-leninowców”. KPU uważała, iż ogłoszenie niepodległości Ukrainy było „zdradzieckim przewrotem kontrrewolucyjnym”, a państwo ukraińskie w ich rozumieniu powstało w sposób nieprawowity. KPU opowiadała się za rezygnacją niepodległości przez Ukrainę, jej powrotem do imperium komunistycznego. Partia KPU w latach 1997-1999 roku proponowała likwidację urzędu prezydenta oraz przekazanie władzy „radom deputowanych ludowych".

Analizując funkcjonowanie elit rządzących na Ukrainie, John Ishijama wprowadza definicję partii następcy na określenie elit, które „odziedziczyły przewagę byłych partii rządzących, ich resursy i personel" ${ }^{63}$. Myśl tę dalej rozwijają Kerstin Zimmer i Olexiy Haran, określając Partię Regionów, wśród innych centrowych partii ukraińskich, jako de facto następcę partii reżimu radzieckiego ${ }^{64}$. Autorzy zauważyli ślad „linii następstwa” od dawnej rządzącej partii komunistycznej Ukrainy Sowieckiej, poprzez elity czerwonych dyrektorów - Ludowo-Demokratyczna Partia, koalicję „O Jedyną Ukrainę!”, do jednego z byłych członków tej koalicji - Partii Regionów, którą teraz przedstawia jej następca Blok Opozycyjny. Zimmer i Haran również zaznaczają, iż rzucająca się w oczy ciągłość zachowania politycznej elity w okresie przed pomarańczową rewolucją i po niej, stanowi główny problem w procesie przemian postsowieckiej Ukrainy. Analizując również wydarzenia po rewolucji godności, możemy wnioskować, że rekonstrukcja nieformalnej praktyki we współczesnej Ukrainie ma potencjał, by fundamentalnie zagrozić procesowi demokratyzacji w państwie.

${ }^{62}$ L. HurSka- KowalczyK: Opozycja polityczna na Ukrainie (1991-2006). Toruń 2011, s. 320 .

63 J.T. Ishiyama: Strange Bedfellows: Explaining Political Cooperation between Communist Successor Parties and Nationalists in Eastern Europe. "Nations and Nationalism" 1998, No 4 (1), s. 62.

${ }^{64}$ K. Zimmer, O. Haran: Unfriendly Takeover: Successor Parties in Ukraine. "Communist and PostCommunist Studies" 2008, No 41, s. 4. 


\section{Wpływ otoczenia międzynarodowego}

Oprócz uwarunkowań wewnętrznych szczególny wpływ na tempo i zaawansowanie procesu demokratyzacji wywiera otoczenie międzynarodowe. Należy zaznaczyć, iż procesy zmiany instytucjonalnej zachodzą nie tylko w kontekście krajowym. Wydarzenia w najbliższym otoczeniu międzynarodowym mają swoje znaczenie dla zaawansowania przekształceń systemowych w poszczególnych państwach.

Ze względu na specyficzne geopolityczne położenie Ukrainy ważną rolę w procesie demokratyzacji tego państwa odgrywają wpływ Federacji Rosyjskiej oraz struktur Zachodu. Zbigniew Brzeziński zalicza Ukrainę do państw geopolitycznie zagrożonych, na których rozwój wpływają regionalne mocarstwa $^{65}$. Kluczowym czynnikiem egzogennym determinującym pomyślność demokratyzacji na Ukrainie jest destrukcyjny wpływ Federacji Rosyjskiej. Faktycznie, od momentu ogłoszenia niepodległości przez Ukrainę, konflikty w stosunkach bilateralnych tych państw zaczęły przybierać na sile. Rosja stosowała różnego rodzaju instrumenty wpływu - polityka informacyjna na wschodzie Ukrainy za pomocą mediów oraz Ukraińskiej Prawosławnej Cerkwi Moskiewskiego Patriarchatu (m.in. propagowanie „Russkiego Miru”), szantaż gazowy, stacjonowanie floty czarnomorskiej na Krymie, podważanie autorytetu Ukrainy jako samodzielnego państwa na arenie międzynarodowej, wtrącanie się w cywilizacyjny wybór Ukraińców poprzez prowadzenie negocjacji z prezydentem Janukowyczem przed podpisaniem Umowy Stowarzyszeniowej z UE, aneksja Krymu oraz wojna hybrydowa w Donbasie. Słusznie zaznacza Krzysztof Falkowski, iż Polsce udało się zacząć proces demokratyzacji w sprzyjającym momencie, gdy Rosja była słaba politycznie na arenie międzynarodowej, a wspólnota międzynarodowa aktywnie pomagała państwom przechodzącym trudny proces transformacji ${ }^{66}$. Obecnie Rosja realizuje neoimperialną politykę, stanowiącą zagrożenie dla demokracji zarówno ukraińskiej, jak i europejskiej. Dlatego zmiany na Ukrainie, pomimo znacznego wsparcia Zachodu, potrzebują większej mobilizacji społecznej oraz determinacji elit rządzących.

${ }^{65}$ Z. BrzezińskiJ: Strategiczne baczennia: Ameryka i kryza globalnoj wlady. Perekl.

G. LeLiw. Lwiw 2012, s. 76.

${ }^{66}$ K. FalKowsKi: Testing the CEE's Model..., s. 22. 


\section{Wyzwania dla tranzytologii płynące z polskiej i ukraińskiej transformacji}

Ukraina, będąc jednym z państw powstałych na gruzach byłego ZSRR, robi znaczne postępy w procesie demokratyzacji, jednak wciąż boryka się z wieloma problemami. Próbą znalezienia teoretycznego modelu dla Ukrainy stała się propozycja „poczwórnej” tranzycji (quadruple transition), którą zaproponował Taras Kuzio ${ }^{67}$. W myśl tej koncepcji transformacja polega na realizacji czterech zadań: transformacji politycznej, transformacji gospodarczej, budowaniu państwa oraz budowaniu narodowej wspólnoty politycznej. Należy zaznaczyć, iż ostatni warunek jest często nieuwzględniany w literaturze tranzytologicznej. Jak pokazują ostatnie wydarzenia na Ukrainie, konieczne jest przemyślenie i teoretyczne uzasadnienie wpływu narodowej wspólnoty politycznej na proces demokratyzacji. Jednym z największych osiągnięć rewolucji godności jest konsolidacja społeczeństwa oraz formowanie ogólnoukraińskiej tożsamości. Kwestie tożsamości i wyboru cywilizacyjnego są ściśle powiązane w ukraińskim społeczeństwie, co wynika z osobliwości podziałów socjopolitycznych w tym kraju. Paradoksalnie, konsolidowanie narodu zostało przyśpieszone przez agresję Rosji w Donbasie. Wysoki poziom patriotyzmu potwierdzają liczne sondaże przeprowadzone przez ukraińskie i zagraniczne organizacje ${ }^{68}$. Na dodatek w społeczeństwie przeważają nastroje eurointegracyjne, o czym również świadczą liczne sondaże i badania ${ }^{69}$. Dodatkowym czynnikiem konsolidującym społeczeństwo

${ }^{67}$ T. Kuzio: Transition in Post-Communist States. Triple or Quadruple? "Politics" 2001, Vol. 21(3), s. 168.

${ }_{68}$ Jak pokazują wyniki ogólnoukraińskiego sondażu zorganizowanego we wrześniu 2015 r. przez Instytut Społecznej i Politycznej Psychologii Ukraińskiej Narodowej Akademii Nauk Pedagogicznych, 92,4\% obywateli Ukrainy akceptuje i popiera ogłoszony w $1991 \mathrm{r}$. Akt o niepodległości Ukrainy. Uchwalenie tego dokumentu poparła większość obywateli we wszystkich regionach: na zachodzie — 97,7\%, w centrum kraju - 95,1\%, na południu $96,6 \%$, na wschodzie - 85,7\%. Pytania zadane respondentom były analogiczne do tych, jakie przedstawiono w referendum w $1991 \mathrm{r}$. W sondażu z $2015 \mathrm{r}$. za poparciem dokumentu opowiedziało się o $16 \%$ osób więcej niż w referendum z 1991 r. (w 1991 r. za niepodległością zagłosowało 90,32\% uczestników referendum, jednak stanowili oni jedynie 76,03\% wszystkich tych, którym przysługiwało bierne prawo wyborcze). W 2014 r. wynik obywateli popierających niepodległość Ukrainy po raz pierwszy przekroczył granicę 90\%. Zobacz więcej: Dumki ta ocynky gromadian na starti wyboriw do Werchownoj Rady Ukrainy. Wereseń 2014: informacyjnyjj buleteń. Red. M. Slusarews'KiJ. Uporiad. L. Czernisz. Kyiw 2014, s. 36 .

${ }^{69} \mathrm{~W}$ wyniku sondażu przeprowadzonego w ramach projektu USAID „sprawiedliwa praworządność", od 26 maja do 20 czerwca 2016 r. 35\% respondentów całkowicie popiera wejście do UE, 22\% odpowiedziało „raczej tak”, 14\% miało neutralne zdanie, 9\% — „raczej nie” oraz 13\% — „zdecydowanie nie”. Respondenci, którzy opowiedzieli się pozytywnie, stanowili $57 \%$. Natomiast wejście Ukrainy do NATO popiera: $25 \%$ — „zdecydowanie tak”, 
stanie się zjednoczenie ukraińskiej Cerkwi Prawosławnej — udzielenie jej autokefalii przez Konstantynopol. Wszystkie te tendencje dają pozytywną nadzieję na przyśpieszenie procesów demokratyzacji w tym kraju.

Tranzytologia w przypadku Polski staje w obliczu innego wyzwania - wytłumaczenia, dlaczego w demokracjach konsolidujących zachodzą negatywne tendencje oraz jakie są możliwości ich odwrócenia. Defekty demokracji w Polsce tkwią w kulturze politycznej, a mianowicie w niezadowoleniu z funkcjonowania głównych instytucji demokratycznych oraz niskiej frekwencji społeczeństwa w wyborach. Badacze także coraz częściej zwracają uwagę na pogarszający się stan demokracji w Polsce, określając go mianem „nieliberalnej demokracji”" Międzynarodowa organizacja The World Justice Project w swoim badaniu dotyczącym rządów prawa na świecie (The Rule of Law Index) odnotowuje, iż Polska zajęła w 2018 roku 25. miejsce spośród 113 państw biorących udział w badaniu, natomiast w 2016 roku jej pozycja była $22^{71}$. Obecnie autorzy publikacji tranzytologicznych próbują udzielić odpowiedzi na pytanie o to, czy tendencje te mają charakter tymczasowy, czy długoterminowy oraz jakich konsekwencji można oczekiwać dla polskiej demokracji.

\section{Podsumowanie}

Dla państw postkomunistycznych od samego początku było problematycznym powtórzenie doświadczeń państw rozwiniętych oraz zastosowanie istniejącego teoretycznego dorobku tranzytologii. W porównaniu do procesu demokratyzacji w Europie Południowej i Ameryce Łacińskiej, transformacja postkomunistyczna odbywa się w całkowicie odmiennych okolicznościach. Państwa Europy Środkowej i Wschodniej stanęły przed koniecznością dokonania innych zadań - realizacji „potrójnej” (triple), a nawet „poczwórnej” (quadruple) transformacji. Jednak wyodrębniając cechy charakterystyczne dla państw

17\% — „raczej tak”, 15\% — zajęło neutralną pozycję, 14\% — „raczej nie”, 20\% —,,zdecydowanie nie". Najwięcej zwolenników wejścia Ukrainy do UE i NATO było w zachodnich i południowych regionach, najmniej — we wschodnich. Tylko co piąty respondent zgadza się z tym, iż Ukraina powinna wznowić polityczne i ekonomiczne relacje z Rosją (najwięcej takich respondentów jest na Wschodzie - 47\%). Jednocześnie 40\% obywateli Wschodu nie może określić się z odpowiedzią na to pytanie - https://newjustice.org.ua/uk/lib/ doslidzhennya-ta-zviti/ (dostęp: 20.10.2018).

${ }^{70}$ A. Agr: Decline of Democracy in the ECE and the Core Periphery Divide. Rule of Law Conflicts of Poland and Hungary with the EU. "Journal of Comparative Politics" 2018, Vol. 11, No 2, s. 30.

${ }_{71}$ The WJP Rule of Law Index — https://worldjusticeproject.org/our-work/wjp-rule-lawindex/wjp-rule-law-index-2017\%E2\%80\%932018 (dostęp: 20.10.2018). 
postkomunistycznych, należy pamiętać, iż społeczeństwa te różnią się między sobą. Jaskrawym przykładem są Polska i Ukraina. Nie zważając na pomyślność procesu demokratyzacji w Polsce, tranzytologia wciąż napotyka nowe wyzwania - znalezienie mechanizmów zapobiegających dalszej erozji demokracji w tym kraju. W przypadku Ukrainy korzystna dla tranzytologów stanie się analiza doświadczeń demokratyzacji w Polsce oraz uwzględnienie ostatnich tendencji zachodzących na scenie politycznej Ukrainy w celu opracowania efektywnego modelu demokratycznej transformacji tego państwa.

\section{Bibliografia}

ÁGH A.: Decline of Democracy in the ECE and the Core Periphery Divide. Rule of Law Conflicts of Poland and Hungary with the EU. "Journal of Comparative Politics" 2018, Vol. 11, No 2.

Antologija konstitucyjnogo procesu w suczasnij Ukraini. Centr Razumwoka. Wydawnictwo „Zapowit 2017”.

Antoszewski A.: System polityczny RP. Warszawa 2012.

Atlas istorii ukrains'koj derżawnosti. Ukrains'ki zemli wid najdawniszych czasiw do s'ogodennia. Red. O. Kupczyns'KiJ, Ju. Loza, O. SzabliJ. Lwiw 2013.

BALuK W.: Koalicje gabinetowe na Ukrainie w latach 2002-2012. Lublin 2012.

BIElasiaK J.: The Institutionalization of Electoral and Party Systems in Postcommunist States. "Comparative Politics" 2002, Vol. 34, No 2.

BLOK Z.: Transformacja jako konwersja funkcji. Poznań 2006.

Bronislawskij E., Wacznadze G.: Polskij dialog. Sobytija w Polsze glazami polskich, sowetskich, amerikanskich, zapadnogermanskich i francuskich żurnalistow. Tbilisi 1990.

Brzezińskiv Z.: Strategiczne baczennia: Ameryka i kryza globalnoj wlady. Perekl. G. LeLIw. Lwiw 2012.

Cichosz M.: Transformacja demokratyczna - przyczyny, przebieg i efekty procesu. W: Systemy polityczne Europy Środkowej $i$ Wschodniej. Perspektywa porównawcza. Red. A. AntoszewsKi. Wrocław 2006.

DobeK-OstrowskA B.: Proces demokratyzacji Europy Środkowo-Wschodniej przesłanki i przebieg. W: Demokracje Europy Środkowo-Wschodniej w perspektywie porównawczej. Red. A. Antoszewski, R. Herbut. Wrocław 1998.

Dumki ta ocynky gromadian na starti wyboriw do Werchownoj Rady Ukrainy. Wereseń 2014: informacyjnyjj buleteń. Red. M. Slusarews'KiJ; uporiad. L. CzerNISZ. Kyiw 2014.

FALKOWSKI K.: Testing the CEE's Model of Transformation in the ENP Framework. Challenges and Opportunities. The Eastern Dimension. "Yearbook of the Institute of East-Central Europe" 2016, Vol. 14, No 6. 
GlajCAR R.: Demokratyczny rezim polityczny. Relacje między legislatywa i egzekutywa w III Rzeczypospolitej. Katowice 2015.

GRYCAK J.: Narys istorii Ukrainy: formuwannia modernoj urkainsjkoj nacyi XIXXX stolittia. Kyiw 2000.

Huntington S.P.: Trzecia fala demokratyzacji. Przeł. A. DziurdziK. Warszawa 1995.

Hurska-KowalczyK L.: Opozycja polityczna na Ukrainie 1991-2006. Toruń 2011.

Ishiyama J.T.: Strange Bedfellows: Explaining Political Cooperation between Communist Successor Parties and Nationalists in Eastern Europe. "Nations and Nationalism" 1998, Vol. 4, Issue 1.

JASKIERnia J.: System rządów w Rzeczypospolitej Polskiej w świetle aktualnych propozycji jego zmian. „Przegląd Prawa Konstytucyjnego 2012.

KolODII A.: Trajektoria demokratycznego przejścia na Ukrainie. W: Transformacja w Polsce i na Ukrainie. Wybrane aspekty. Red. A. Antoszewski, A. Kolodi, K. KowalczyK. Wrocław 2010.

Kolodis A.: Zagalmowana transformacija i majbutne ukrains'koj mrii pro demokratycznu prawowu derżawu — http://political-studies.com/?p=901 (dostęp: 20.10.2018).

Kolodis A.: Politiczna transformacija w Ukraini: institucyi ta ludy. „Efektywnist' derżawnogo uprawlinnia" 2007, wyp. 12. Lwiw.

KowalsKa M.: Ombudsman w procesie transformacji ustrojowej w Polsce $i$ innych krajach europejskich. W: Modernizacja polityczna w teorii i praktyce. Doświadczenia państw postsocjalistycznych $i$ Trzeciego Świata. Red. M. BARAŃSKI. Katowice 2009.

Kuzio T.: Transition in Post-Communist States: Triple or Quadruple? "Politics" 2001, Vol. 21(3).

LANOWYJ W.: Skromna czariwnist' oligarchii. Ekonomiczna prawda, 26 listopada 2013 — https://www.epravda.com.ua/publications/2013/11/26/405262/?fbclid=Iw AR0PtPd2yd5-t3Vh-tq3yucjOnEQ4_EN5uBGK21LmmKv3HTT3QRQsQBgnyc (dostęp: 20.08.2018).

Linz J.J, Stepan A.: Problems of Democratic Transition and Consolidation. Southern Europe. Baltimore 1996.

Lorencka M., Myśliwiec M., Wojtasik W.: Evolution of the Political System in Poland after 1989. In: Democratization processes in Poland and Slovenia: Comparative Study. Ed. A. Turska-KaWA, M. HaČEK. Maribor 2016.

Migalski M.: Czeski i polski system partyjny. Warszawa 2008.

Morawski W.: Zmiana instytucjonalna. Warszawa 1998.

MoтyL O.: Jak zrozumity Ukrainu? „Kritika” 1998, № 1(3).

OfiCyns'KiJ R.: Politycznyjj rozwitok nezależnoj Ukrainy (1991-2004) w aspekti ewropejs'koj identycznosti. Użgorod 2005.

Olechno A.: Instytucja Prezydenta w systemie konstytucyjnych organów Ukrainy. Toruń 2009.

Piasecki A., Michalak R.: Polska 1945-2015. Historia polityczna. Warszawa 2016. 
Postanowa Werchownoj Rady Ukrainy „Pro poperedne schwalennia zakonoproektu pro wnesennia zmin do Konstytucyi Ukrainy szczodo decentralizacyi wlady" http://zakon2.rada.gov.ua/laws/show/656-19 (dostęp: 30.06.2018).

Ricznica smerti Wiaczeslawa Czornowola: ukrainci wymagajut' znajty wynnych https://uain.press/articles/richnytsya-smerti-v-yacheslava-chornovola-ukrayintsi-vymagayut-znajty-vynnyh-765112 (dostęp: 20.10.2018).

Rostou D.: Perechody $w$ demokratii: popytka dinamiczeskoj modeli. „Polis” 1996, № 5 .

RyBiy O.: Party System Institutionalization in Ukraine. "Democratizatsiya" 2013, No 21.

Surmacz B.: Współczesne stosunki polsko-ukraińskie. Politologiczna analiza traktatu o dobrym sasiedztwie. Lublin 2002.

Transparency International: korumpowani oligarchiczni klany wbiwajut' w Ukraini czesnyj biznes. ZN.UA, 3 grudnia 2013 roku — https://dt.ua/ECONOMICS/transparency-international-korumpovani-oligarhichni-klani-vbivay ut-v-ukrayini-chesniy-biznes-133087_html?fbclid=IwAR1yg-zypymPRckpxVyQwwfacauem71Hymz22iXWMivI58Ed1J4mRi2nSo (dostęp: 20.08.2018).

TrofanczuK G.: Istorija derżawy ta prawa Ukrainy. Nawczalnyj posibnyk. Kyiw 2017.

Turczenko F., Panczenko P., Timczenko S.: Nowitnia istorija Ukrainy. Pidrucznik. Kyiw 2005.

The WJP Rule of Law Index - https://worldjusticeproject.org/our-work/wjp-rule-law-index/wjp-rule-law-index-2017\%E2\%80\%932018 (dostęp:20.10.2018).

Wiatr J.: Pięć parlamentów III Rzeczpospolitej. W: Demokracja Polska 19892003. Red. J. Wiatr, J. Raciborski, J. Bartkowski, B. Frączak-Rudnicka. Warszawa 2003.

Wiatr J.: Polska droga do demokracji. W: Demokracja Polska 1989-2003. Red. J. Wiatr, J. Raciborski, J. Bartkowski, B. Frączak-Rudnicka, J. Kilias. Warszawa 2003.

Zimmer K., Haran O.: Unfriendly Takeover. Successor Parties in Ukraine. "Communist and PostCommunist Studies" 2008, No 41.

Znimalna grupa filmu "Stus" obicaje powernuty do kartyny scenu sudylyszcza za uczastiu Medwedczuka — https://espreso.tv/news/2018/08/11/znimalna_grupa filmu_quotstusquot_obicyaye_povernuty_do_kartyny_scenu_sudylyscha_za_ uchastyu_medvedchuka (dostęp: 22.10.2018).

Natalia Rudakiewicz, mgr politologii, doktorantka Wydziału Nauk Społecznych Uniwersytetu Śląskiego w Katowicach. Jej zainteresowania badawcze skupiają się na problematyce stosunków polsko - ukraińskich, a także perspektyw demokratycznej transformacji państw obszaru byłego Związku Radzieckiego. 